\title{
Dialogic Federalism: Constitutional Possibilities for Incorporation of Human Rights Law in the United States
}

Catherine Powell

Georgetown University, cp443@law.georgetown.edu

Georgetown Public Law and Legal Theory Research Paper No. 12-115

This paper can be downloaded free of charge from:

https://scholarship.law.georgetown.edu/facpub/1008

http://ssrn.com/abstract=2130128

150 U. Pa. L. Rev. 245-295 (2001)

This open-access article is brought to you by the Georgetown Law Library. Posted with permission of the author. Follow this and additional works at: https://scholarship.law.georgetown.edu/facpub 


\title{
DIALOGIC FEDERALISM: CONSTITUTIONAL POSSIBILITIES FOR INCORPORATION OF HUMAN RIGHTS LAW IN THE UNITED STATES
}

\author{
CATHERINE POWELL ${ }^{\dagger}$
}

\begin{abstract}
Where, after all, do universal rights begin? In small places, close to home-so close and so small that they cannot be seen on any maps of the world. ... Unless these rights have meaning there, they have little meaning anywhere. Without concerned citizen action to uphold them close to home, we shall look in vain for progress in the larger world.
\end{abstract}

-Eleanor Roosevelt ${ }^{1}$

While the U.S. Constitution assigns the power to make and adopt treaties to the federal government, several state and local governments have "adopted" human rights treaties and other international norms, often in response to constituent pressures that are more effectively mobilized at the subnational level. ${ }^{2}$ For example, in the absence of federal ratification of the Convention on the Elimination of All

'Associate Clinical Professor of Law, Columbia Law School; Executive Director, Human Rights Institute; B.A., Yale University (1987); M.P.A., Princeton University, Woodrow Wilson School in Public and International Affairs (1991); J.D., Yale Law School (1992). I would like to thank the following people for their generous advice, support, and encouragement: Jose Alvarez, Eyal Benvenisti, Michael Dorf, Martin Flaherty, Katherine Franke, Louis Henkin, James Liebman, Henry Monaghan, Gerald Neuman, Mark Quarterman, Judith Resnik, Peter Spiro, Susan Sturm, and Kendall Thomas. I would also like to acknowledge Giliane Cherubin and Rabecca Cross for their invaluable research assistance, as well as Paul Bond and Meghan Irmler of the University of Pennsylvania Law Review.

1 Eleanor Roosevelt, Address at a United Nations Ceremony in New York (Mar. 27, 1958), in Peter Meyer, The International Bill of Human Rights: A Brief History, at http://paulwilliams.com/globalrights/history.html (citation omitted).

"I have put "adopted" in quotes because state and local governments cannot technically adopt treaties, although they can incorporate international human rights standards into state and local law simply by enacting legislation reflecting these norms. While the Constitution provides that the President "shall have Power, by and with the Advice and Consent of the Senate to make treaties, provided two thirds of the Senators present concur," U.S. CONST. art. II, $\S 2$, cl. 2, it specifically prohibits state governments from making treaties without the consent of Congress, id. at art. I, $\S 10$, cl. 3 . For the purposes of this Article, I capitalize "States" to refer to nation-states in the international law sense, and de-capitalize "states" to refer to the 50 states of the United States. 
Forms of Discrimination Against Women (CEDAW), ${ }^{3}$ San Francisco has incorporated "principles of CEDAW" into binding local law. ${ }^{4}$ In the death penalty context, where the federal government has not yet opted to ratify the Second Optional Protocol to the International Covenant on Civil and Political Rights (Second Optional Protocol to the ICCPR), ${ }^{5}$ aimed at the abolition of the death penalty, a handful of cities have urged their states, and in some cases the federal government, to support a moratorium, relying on the United Nations Commission on Human Rights' call for such a moratorium. ${ }^{6}$

What are the constitutional implications of this and other moves to bypass the federal government in incorporating and enforcing international human rights? Discussions about the allocation of authority between federal and subfederal systems in the implementation of international human rights law typically proceed by staking out one of two initial positions. ${ }^{7}$ At one end of the spectrum, a traditional constitutional theory takes a restrictive view of state and local authority, envisioning hierarchical imposition of federally implemented international law norms through the federal treaty power ${ }^{8}$ and determination

${ }^{3}$ Convention on the Elimination of All Forms of Discrimination Against Women, opened for signature Dec. 18, 1979, 1249 U.N.T.S. 13 [hereinafter CEDAW].

${ }^{4}$ See SAn Francisco, Cal., Administrative Code, ch. 12K (2001) (providing the local San Francisco law entitled "Local Implementation of the United Nations Convention on the Elimination of All Forms of Discrimination Against Women (CEDAW)"), available at http://www.amlegal.com/sanfranadmin/lpext.dll?f=templates\&cfn=mainj.htm\&2.0.

${ }^{5}$ Second Optional Protocol to the International Covenant on Civil and Political Rights, Aiming at the Abolition of the Death Penalty, U.N. GAOR 3rd Comm., 54th Sess., Annex, at 14, U.N. Doc. A/44/824 (1989), reprinted in 1989 U.N.Y.B. 484. For Congressional discussion on the rejection of the Second Optional Protocol, see U.S. Reservations, Understandings, and Declarations to the International Covenant on Civil and Political Rights, 138 CONG. REC. 8068, 8071 (1992) [hereinafter U.S. RUDs to the ICCPR]. For the treaty itself, see the International Covenant on Civil and Political Rights, opened for signature Dec. 16, 1966, S. EXEC. Doc. E, 95-2, at 23, 999 U.N.T.S. 172, 173 [hereinafter ICCPR].

${ }^{6}$ For discussion, see infra notes 157-60 and accompanying text.

${ }^{7}$ I have adapted discussion of the following two positions from a framework developed by Robert M. Cover and T. Alexander Aleinikoff in the context of habeas corpus law to fit the international human rights law context. See Robert M. Cover \& T. Alexander Aleinikoff, Dialectical Federalism: Habeas Corpus and the Court, 86 YALE L.J. 1035,1047 (1997) (making a similar observation in the context of habeas corpus law, in which two paradigms were developed and defended: "a model of hierarchical imposition of federally determined values; and a model of fragmentation, justifying value choices by the states"). I am indebted to Judith Resnik for bringing this article to my attention.

${ }^{8}$ The Supreme Court has opined, "No doubt the great body of private relations usually fall within the control of [a] state, but a treaty may override its power." Mis- 
of customary international law ${ }^{9}$ by federal courts. ${ }^{10}$ At the other end of the spectrum, a revisionist theory assumes greater fragmentation and authority reserved to the states based on federalism and separation of powers limits on federal authority." "These divergent images capture

souri v. Holland, 252 U.S. 416, 434 (1920) (holding that the treaty power authorizes Congress to legislate under the Necessary and Proper Clause in areas beyond those specifically conferred in Article 1, Section 8, of the U.S. Constitution and that the treaty power is not subject to most Tenth Amendment limitations); see also Martin S. Flaherty, Are We to Be a Nation? Federal Power vs. "States' Rights" in Foreign Affairs, 70 U. COLO. L. REV. 1277, 1280 (1999) (arguing that the "federal foreign affairs authority does and should trump the prohibition against the national government enlisting state officials"); David M. Golove, Treaty-Making and the Nation: The Historical Foundations of the Nationalist Conception of the Treaty Power, $98 \mathrm{MICH}$. L. REv. 1075, 1314 (2000) (“[T] he nationalist conception of the treaty power... finds its ultimate justification in the Founders' decision to lodge the whole of the foreign affairs powers exclusively in the national government.").

" "Customary international law results from a general and consistent practice of [s] tates followed by them from a sense of legal obligation." RESTATEMENT (THIRD) OF THE FOREIGN RELATIONS LAW OF THE UNITED STATES $§ 102$ (1986).

${ }^{10}$ See, e.g., Ryan Goodman \& Derek P. Jinks, Filartiga's Firm Footing: International Human Rights and Federal Common Law, 66 FoRDHAM L. REV. 463, 529 (1997) ("[F]or nearly twenty years, the federal government ... has spoken with one voice on the status of [customary international law (CIL)] in U.S. law: [u]niversally-recognized human rights are judicially-cognizable federal law."); Louis Henkin, International Law as Law in the United States, 82 MICH. L. REV. 1555, 1569 (1984) (“[T]he law of nations, which is the responsibility of the U.S. nation, should be seen as incorporated in our national jurisprudence as national (federal) law."); Harold Hongju Koh, Is International Law Really State Law?, 111 HARV. L. REV. 1824, 1824 (1998) (“[J]udicial determinations of international law-including international human rights law-are matters of federal law."); Gerald L. Neuman, Sense and Nonsense About Customary International Law: A Response to Professors Bradley and Goldsmith, 66 FoRDHAM L. REV. 371, 376-77 (1997) ("Incorporation at the federal level respects the national character of foreign relations: the [s] tates are not entitled to adopt individual approaches to international law."); Beth Stephens, The Law of Our Land: Customary International Law as Federal Law After Erie, 66 FORDHAM L. REV. 393, 397 (1997) (arguing that "the determination of the content of customary international law and of whether or not it applies in a given situation is a federal question, which triggers federal court jurisdiction and on which federal court decisions are binding on the states").

${ }^{11}$ See, e.g., Curtis A. Bradley \& Jack L. Goldsmith, III, The Current Illegitimacy of International Human Rights Litigation, 66 FORDHAM L. REV. 319, 349 (1997) [hereinafter Bradley \& Goldsmith, Current Illegitimacy] (contending, based on the famous proclamation in Erie Railroad Co. v. Tompkins, 304 U.S. 64, 78 (1938), that "[t]here is no federal general common law," and that determinations of CIL are questions of state law which "federal courts should not apply ... as federal law without some authorization to do so by the federal political branches"); Curtis A. Bradley \& Jack L. Goldsmith, Customary International Law as Federal Common Law: A Critique of the Modern Position, 110 HARV. L. REv. 816, 816-21 (1997) [hereinafter Bradley \& Goldsmith, Critique of the Modern Position] (characterizing the traditional approach-which assumes CIL is a type of federal common law-as a "modern position" that is inconsistent with federalism; courts should not apply CIL as federal law unless authorized to do so by the federal political branch $\rightarrow$ Jack L. Goldsmith, Federal Courts, Foreign Affairs, and Federalism, 83 
different moments of political promise and despair, at times focused on the immense power of the national project, and other times appreciating the vitality and durability of forms of governance that, without ... great resources, continue to have social and political force." ${ }^{12}$

Under both models, one system-either federal or subfederalhas a predominant voice in deciding when and how international human rights law is implemented. Such either/or approaches seek to avoid the conflict and indeterminacy created when the distribution of constitutional authority is uncertain. ${ }^{13}$ At the traditional/hierarchical end of the spectrum, the conflict is interference with the ability of the nation to speak with "one voice" in foreign affairs, ${ }^{14}$ posed by "divergent and perhaps parochial state interpretations" of international law. ${ }^{1.5}$ At the revisionist/fragmentation end, the conflict, at its core, is

VA. L. REV. 1617, 1622 (1997) [hereinafter Goldsmith, Federal Courts] (arguing that the federal common law of foreign relations as currently practiced by courts and understood by scholars lacks justification); see also Curtis A. Bradley, The Treaty Power and American Federalism, 97 MICH. L. REv. 390, 394 (1998) [hereinafter Bradley, Treaty Power] (arguing that the unlimited power of treaty makers over states is inconsistent with American federalism).

$\dddot{\rightarrow}$ Judith Resnik, Afterword: Federalism's Options, 14 YALE L. \& POL'Y REv. 465, 500 (1996) (concluding a symposium on "Constructing a New Federalism: Jurisdictional Competition and Competence").

${ }^{13}$ See Cover \& Aleinikoff, supra note 7, at 1047 ("Both paradigms create a sense that conflict and indeterminacy are dysfunctional.").

${ }^{14}$ See, e.g., Crosby v. Nat'l Foreign Trade Council, 530 U.S. 363, 381 (2000) (emphasizing the need for the President to speak for the nation with one voice in dealing with other governments); Boyle v. United Techs. Corp., 487 U.S. 500, 508 n.4 (1988) (finding "distinctive federal interest in ... the exterior relation of this whole nation with other nations and governments" (internal quotation marks and citations omitted)); Japan Line, Ltd. v. County of Los Angeles, 441 U.S. 434, 448 (1979) (“'In international relations and with respect to foreign intercourse and trade the people of the United States act through a single government with unified and adequate national power." (quoting Bd. of Trs. of Univ. of Ill. v. United States, 289 U.S. 48, 59 (1933))); Zschernig v. Miller, 389 U.S. 429, 437-38 (1968) (Stewart, J., concurring) (“[T] he conduct of our foreign affairs is entrusted under the Constitution to the National Government, not for local probate courts of the several states."); United States v. Belmont, 301 U.S. 324, 330 (1937) ("Governmental power over external affairs is not distributed, but is vested exclusively in the national government. And ... the Executive ha[s] authority to speak as the sole organ of that government.").

${ }_{15}$ Banco Nacional de Cuba v. Sabbatino, 376 U.S. 398, 425 (1964). The Court also stated that "ordering our relationships with other members of the international community must be treated exclusively as an aspect of federal law." Id. Sabbatino relied on an influential article by Professor (later International Court of Justice Judge) Phillip C. Jessup, who argued that Justice Brandeis' famous pronouncement in Erie, 304 U.S. at 78, that "[t] here is no federal general common law," had (in Jessup's words) "no direct application to international law." Philip C. Jessup, The Doctrine of Erie Railroad v. Tompkins Applied to International Law, 33 AM. J. INT'L L. 740, 741 
interference with states' rights by federal courts (without authorization to do so by the federal political branches) and by the political branches (particularly Congress, when it exercises the treaty power to legislate in areas beyond those specifically conferred in the U.S. Constitution, Article 1 , Section 8). ${ }^{16}$ While the two paradigms described here are idealized and oversimplify the subtlety and hybridity within these paradigms, in fact much of the scholarship on federalism and human rights law in the United States loosely tracks one or the other of these two models, if not always in its purest form.

This Article argues for a third approach, premised on dialogue and intergovernmental relations as a way to negotiate, rather than avoid, conflict and indeterminacy. ${ }^{17}$ This approach links national and subnational governments in a dialogue about rights by "creat[ing] areas of overlap in which neither system can claim total sovereignty." The dialogue emerges in these areas of overlap, particularly where differences arise in the extent to which national and subnational governments incorporate human rights obligations. Conflict and inde-

(1939). For more recent discussion of the same point, see Koh, supra note 10, at 1832, arguing that designating state courts as the primary interpreters of CIL "would have raised the specter that multiple variants of the same international law rule could proliferate among the several states."

${ }^{16}$ Bradley \& Goldsmith, Critique of the Modern Position, supra note 11; Bradley \& Goldsmith, Current Illegitimacy, supra note 11.

${ }^{17}$ Cover \& Aleinikoff, supra note 7, at 1048 (proposing a model of federal-state interaction and dialogue to address conflict and indeterminacy in the context of habeas law). For discussion about the need for a new dynamic approach to federalism generally, see, for example, Michael D. REAGan \& John G. SANZONE, THE NEW FEDERALISM 3 (2d ed. 1981), stating: "Federalism-old style-is dead. Yet federalism-new style-is alive and well and living in the United States. Its name is intergovernmental relations." I view the third approach offered here as consistent with an emerging body of scholarship on federalism and human rights law located along the middle of the spectrum described above. This emerging body of scholarship includes, for example, Judith Resnik, Categorical Federalism: Jurisdiction, Gender, and the Globe, 111 YAI.F L.J. (forthcoming 2001) (arguing that we should be less categorical about allocation of authority between national and subnational governments); and Peter J. Spiro, The States and International Human Rights, 66 FORDHAM L. REV. 567, 568-69 (1997) (arguing for direct liability for subnational entities-state and local governments-under international law, as well as authority for these entities to "discreetly associate with formal human rights regimes"). Aspects of scholarship that incline toward the traditional end of the spectrum indicate sympathy for the hybridity captured by the middle of the spectrum. See, e.g., Koh, supra note 10, at 1858 (noting that a "zero-sum image of state-federal competition leads Bradley and Goldsmith to downplay the multiple channels through which international human rights norms trickle down to the states from the federal government"). However, the approach outlined in this Article suggests that these norms trickle up as well as down.

${ }^{18}$ Cover \& Aleinikoff, supra note 7, at 1048. 
terminacy are desired conditions, so long as mechanisms exist to channel and resolve these differences and ambiguities, as a means of clarifying and articulating international human rights domestically. By contrast, where one system has sovereignty to act without the consensus and support of the other, the reach of international human rights law lacks both depth and breadth. Under the traditional/hierarchical model, human rights law lacks depth and concreteness because the democratic deficit inherent in the formation and ratification of treaties ${ }^{19}$ disables the federal government from gaining support for human rights at the state and local level. Under the revisionist/fragmentation model, human rights law lacks breadth and national impact in the absence of some form of national cooperation and coordination. By requiring intergovernmental cooperation and dialogue, the third approach offered here facilitates the difficult process of working out how to convert abstract international law principles into concrete, workable domestic laws and policies with national reach.

I call this arrangement "dialogic federalism" because it is based on the assumption that dialogue among various levels of government is critical to meaningful implementation of international human rights law in the United States. ${ }^{20}$ It also assumes that engagement in this intergovernmental dialogue occurs hand in hand with dialogue between and among various international, national, and subnational actors and constituencies. Rather than facilitate mere transmission of the international, then, this approach envisions a process of translation of international to national. ${ }^{21}$ "Just as we know that translation from one language to another requires more than literalness, we must recognize the creativity, and therefore the uncertainty, involved in domestic interpretation [of international law.] ${ }^{, 22}$ After all, while translation owes

${ }^{19}$ See infra notes 28, 92-94 and accompanying text (discussing the lack of public access to and engagement in the treaty-making process).

${ }^{20}$ I am grateful to Kendall Thomas, who identified the term "dialogic federalism" in valuable comments he provided to me on an earlier draft of this Article. While Cover and Aleinikoff, supra note 7, call the conceptual framework they developed in the habeas context "dialectic federalism," I prefer the phrase "dialogic federalism" in the context I address here, to stress the central importance of dialogue in implementing international norms, the legitimacy of which is questioned prior to democratic consideration and adoption of these norms.

${ }^{21}$ See Karen Knop, Here and There: International Law in Domestic Courts, 32 N.Y.U. J. INT'L L. \& POL. 501, 504-05 (2000) (arguing that genuine domestic incorporation of international law involves more than "a conveyor belt that delivers international law to the people").

Id. at 506 . 
fidelity to the other's language and text (the "other" here being international law), it also requires assertion of one's own language as well ("one's own" being domestic law). "The ideal is thus neither wholly international nor wholly national, but a hybrid that express[es] the relationship between them." ${ }^{24}$ The negotiation between international and domestic legal regimes, and the hybridity which results, are the driving forces behind translation of broad international principles into concrete articulation of rights reflected domestically in law and practice. $^{25}$

The translation metaphor is central to the model of dialogue envisioned in this Article, because it captures the foreignness that many Americans associate with international law. As a formal matter, ratified treaties and customary international law are law of the land in the United States. ${ }^{26}$ As a practical matter, however, international law is often viewed as an alien source of law, lacking democratic legitimacy. This latter view is reflected in Supreme Court jurisprudence. ${ }^{27}$ Translation from international to domestic law through broad-based democratic deliberation and discussion is necessary to address the democratic deficit inherent in the ways international law is implemented in the United States. While particular democratic deficits characterize lawmaking processes in the United States generally, ${ }^{28}$ this Article argues that the problem is aggravated in the making and implementation of international law because of lack of transparency in the international processes in which treaties are negotiated as well as in the domestic processes by which treaties are ratified by the Senate, without input from the House, unlike purely domestic legislation. By allowing incorporation of international law through multiple points of

23

Id. (citing JAMES BOND White, Justice As TRANSLATION: AN ESSAY IN Cultural AND LeGAL Criticism 264 (1990)).

${ }^{24} I d$.

2.5 Cf. id. (citing Homi K. Bhabha, The Commitment to Theory, NEW Formations, Summer 1988, at 5, 22 (stating "that it is the 'inter'-the cutting edge of translation and negotiation" that opens a space in which "we will find those words with which we can speak of Ourselves and Others")).

${ }^{201}$ For discussion see infra notes 49-50, 52 and accompanying text.

${ }^{27}$ For discussion see infra notes 51,53 and accompanying text.

28 See, e.g., Jerry L. Mashaw, Greed, ChaOs, and Governance: Using Public CHOICE TO IMPROVE PUBLIC LAW 12 (1997) ("[T] he message [of public choice literature] is ... about why political markets cannot work to satisfy the democratic wish, that is, to provide the people with the government that they want."); Koh, supra note 10, at 1854 (describing domestic federal legislation as "a process notoriously dominated by committees, strong-willed individuals, collective action problems, and private rentseeking”). 
entry, dialogic federalism facilitates translation at various sites with broader participation, ensuring thicker, more complex understandings of human rights law.

This dialogic approach is both descriptive and prescriptive. It is descriptive in that it theorizes by looking at existing intergovernmental collaboration and dialogue. Dialogic federalism is also prescriptive in that it encourages state and local participation even where none exists and posits a constitutional analysis about this participation. The constitutional analysis draws inspiration from scholarship on democratic experimentalism, a theory of American constitutionalism that reinterprets democratic deliberation as a means of reducing the distance between two visions of the Constitution. ${ }^{2.9}$ One vision rests on the Madisonian ideal of limited government based on complex divisions of powers. ${ }^{30}$ The other rests on the New Deal synthesis involving an all-powerful Congress that delegates much of its authority to expert agencies, which are presumably checked through judicial oversight when rights are violated. ${ }^{31}$ Dialogic federalism extends this theory by investigating new modes of democratic deliberation in the context of domestic implementation of international human rights law. In the international human rights context, these new modes of democratic deliberation must resolve the tension between the Madisonian project's commitment to decentralizing authority ${ }^{3 / 2}$ and the fact that the Constitution created national institutions "precisely to avoid such balkanization of foreign policy and international affairs."

29. See Michael C. Dorf \& Charles F. Sabel, A Constitution of Democratic Experimentalism, 98 COLUM. L. REV. 267, 289 (1998) (conceiving of a new decentralized vision of government, "democratic experimentalism," through which the federal government partners with state and local governments to facilitate more participatory and democratic modes of lawmaking).

Id. at 289.

${ }^{31}$ Id. at $290-91$.

${ }^{32}$ Dorf and Sabel assert:

Madison's understanding of the crucial role of power allocation led him to believe that " $[t]$ he end of constitutional [as opposed to statutory] interpretation was to determine which branch or level of government possessed the right to act in a particular area of governance, and in doing so, to preserve the equilibrium among institutions that the Constitution intended to establish."

$I d$. at 289 n.66 (quoting JaCK N. RAKOVE, ORIGINAL MEANINGS: POlITICS AND IDEAS IN THE MAKING OF THE CONSTITUTION 345 (1996)).

${ }^{33} \mathrm{Koh}$, supra note 10 , at 1841 . In fact Madison was aware of this very need for national institutions. See id. at 1825 n.4 (citing THE FEDERALIST No. 42, at 264 (James Madison) (Clinton Rossiter ed., 1961), and indicating that "[b]oth Edmund Randolph and James Madison complained at the Constitutional Convention about the Constitutional Congress's inability to give effect to the law of nations under the Articles of Con- 
As a constitutional thesis, dialogic federalism reveals what both the traditional/hierarchical and revisionist/fragmentation models fail to fully capture and offers a normative framework for negotiating (rather than avoiding) the conflict and indeterminacy inherent in overlapping jurisdiction between national and subnational governments. While these other models anticipate overlapping jurisdiction, ${ }^{34}$ both seek to avoid possible conflicts through trumps: federal supremacy at one end of the spectrum, and states' rights at the other. By contrast, dialogic federalism embraces conflict and utilizes it productively through reliance on dialogue, coordination, and negotiation, rather than trumps. By advancing a more consensus-based process that depends on multiple and concurrent levels of deliberation, this approach seeks to address shortcomings inherent in both federallyimposed mandates (which often fail to gain support at the state and local level) ${ }^{3.5}$ and fragmented state and local initiatives (which often fail to translate into full-scale national compliance with international human rights laws absent coordination and dialogue).

In offering a preliminary sketch of dialogic federalism, this Article is a first step in a larger theoretical project concerning a core dilemma confronting the human rights project: how to square the idea of universal international standards with the tendency toward localism and particularity. ${ }^{36}$ Often asserted as a reaction to globalization, regional integration, and harmonization, localism (or, in the European context, "subsidiarity") resists homogenization and seeks to protect diversity and difference among national and subnational systems. Localism, therefore, asserts that decision making should be on the lowest possible level, and involve individuals, as opposed to their representatives, to the greatest extent possible. The initial conclusion which is introduced here, but which clearly requires further development, is that a federated society such as the United States (or the European Union) will be better equipped to resolve these tensions by developing methods of democratic deliberation that bridge, on the one hand, the society's structural permeability to international human rights

federation").

${ }^{34}$ For example, these competing paradigms anticipate both federal and state courts having jurisdiction (though not always concurrently) over CIL.

${ }^{35}$ The backlash against affirmative action, busing, and other federally-imposed civil rights remedies might be read as a failure of top-down approaches, absent efforts to gain support at the state and local level.

${ }^{36}$ I have explored a related clash between universality and cultural relativism in Catherine Powell, Locating Culture, Identity and Human Rights, 30 COLUM. HUM. RTS. L. REV. 201 (1999). 
norms through multiple points of entry with, on the other hand, the coordination and extraction of these norms at the national level.

This Article questions the efficiency of enabling fifty different legislative campaigns to promote human rights standards, rather than one. By the same token, this piece asks whether there can be any shortcuts. ${ }^{37}$ While I do not have any empirical evidence at this stage of my project to suggest whether or not state and local processes are more open to individuals who wish to engage in standard setting, my argument is simply that "localizing" international human rights law creates opportunities for standard setting that supplement, solidify, and deepen opportunities at the federal level. ${ }^{38}$

Even assuming that the federal government undertook greater leadership in ratifying additional human rights treaties, in more fully implementing those it has not ratified, or in withdrawing reservations to treaty provisions, the argument here is that there would still be a value in state and local participation. By enabling democratic deliberation at multiple levels, dialogic federalism facilitates a broader and deeper consensus over human rights commitments. At the same time, this approach depends on some form of coordination at the federal level, either by the federal government, a national network of state and local governments, or a national nongovernmental structure. Because this paradigm relies on state and local government adoption of human rights standards as a supplement or enhancement to (not as a replacement or diminution of) the role of the federal government, it contrasts with the position taken by revisionist international law scholars. In arguing that the federal government's ability to implement, interpret, and enforce international law should be limited on grounds of federalism and separation of powers, these scholars would disable, rather than bolster, federal authority.

Part I of this Article describes current challenges, in which the

${ }^{37}$ I would like to acknowledge Eyal Benvenisti for raising these important questions in helpful comments on an earlier draft of this Article.

${ }^{38}$ Cf. Mark Tushnet, Keeping Your Eye on the Ball: The Significance of the Revival of Constitutional Federalism, 13 GA. ST. U. L. REV. 1065, 1069-71 (1997) (suggesting that enabling links between subnational governments and transnational networks might be a way of reducing the democratic deficit in American politics).

${ }^{39}$ See, e.g., Bradley \& Goldsmith, Critique of the Modern Position, supra note 11, at 870 ("We have argued that, in the absence of federal political branch authorization, [CIL] is not a source of federal law."); Bradley \& Goldsmith, Current Illegitimacy, supra note 11 , at 368-69 (" $[\mathrm{T}]$ he . . . view that the new CIL is automatically incorporated into federal common law is inconsistent with fundamental constitutional values. ... [C] urrent federal statutes do not support incorporation of substantive rules of the new CIL of human rights."). 
public is largely disengaged from the primary processes through which human rights law is incorporated by the federal government, because these processes discourage direct, broad-based deliberation of subject matter viewed as highly technical and not immediately applicable to people's daily lives. Part II investigates dialogic federalism as a possible solution. Part III describes three different types of dialogic federalism and provides case studies illustrating the first and most frequent form in which state and local governments adopt international human rights standards where the federal government has failed to ratify a treaty. Part IV of this Article locates dialogic federalism within the context of other scholarship on domestic incorporation of international law in the United States and points to its contribution as an alternate framework.

\section{CURRENT CHALlENGES}

In other areas of law, scholars applaud what they describe as new forms of governance, in which power is decentralized away from the national government to enable citizens and other actors to utilize local knowledge in crafting solutions that more tightly fit local circumstances. ${ }^{40}$ Yet, in the realm of international law, the predominant view is that the federal government has a virtual monopoly in foreign affairs and in the development of the two main sources of public international law-treaties and customary international law. ${ }^{41}$ This view (represented in the traditional/hierarchical model described above) is overwhelmingly supported by the Framers' vision of the nation, ${ }^{42}$ the

40 See, e.g., Dorf \& Sabel, supra note 29 (describing role for state and local governments to work in partnership with the federal government to facilitate participatory and democratic approaches to lawmaking).

${ }^{41}$ But see infra Part IV for discussion of opposing views of revisionist scholars.

${ }^{42}$ See, e.g., THE FEDERALIST No. 80, at 476 (Alexander Hamilton) (Clinton Rossiter ed., 1961) (" $[\mathrm{T}]$ he peace of the WHOLE ought not to be left at the disposal of a PART. The Union will undoubtedly be answerable to foreign powers for the conduct of its members.”); THE FEDERALIST NO. 42, at 264 (James Madison) (Clinton Rossiter ed., 1961) ("If we are to be one nation in any respect, it clearly ought to be in respect to other nations."); Henkin, supra note 10, at 1559 n.19 (quoting 2 THE FEDERALIST No. 42, at 50 (James Madison) (New York, 1788)), in which James Madison "justified the clause in the Constitution giving authority to Congress to define offenses against the law of nations and criticized the absence of such authorization in the Articles of Confederation, which 'consequently [left] it in the power of any indiscreet member [i.e., state] to embroil the confederacy with other nations"'); id. at 1560 n.22 (quoting 2 The FedEralist No. 80, at 305 (Alexander Hamilton) (New York, 1788), in which “Alexander Hamilton cites 'cases arising upon treaties and the laws of nations' as proper for the jurisdiction of federal courts"). 
Constitution, ${ }^{43}$ international law, ${ }^{44}$ and Supreme Court precedent reflecting constitutional and policy considerations regarding the need for the nation to speak with "one voice" in foreign affairs. 45 "Every schoolchild knows that the failures of the Articles of Confederation led to the framing of the Constitution, which established national governmental institutions to articulate uniform positions on such uniquely federal matters as foreign affairs and international law." ${ }^{46}$ However, these institutions-federal courts (in the context of litigation based on customary international law or treaty claims) and the Senate and executive branch (in the treaty-making context)-discourage direct broad-based participation. The relative absence of public engagement in these institutions contributes to the failure of these institutions to translate fully international law into domestic law.

For a discussion of additional historical evidence, see FREDERICK W. MARKS III, INDEPENDENCE ON TRIAL: FOREIGN AFFAIRS AND THE MAKING OF THE CONSTITUTION 200-06 (2d ed., Scholarly Res. Inc. 1986) (1973), explaining the significance of foreign affairs in the creation of the Constitution, and the Framers' view of a strong central government; and Flaherty, supra note 8, at 1309-15, noting the Founders' commitment to nationalism in the realm of foreign affairs.

${ }^{43}$ Compare U.S. CONST. art. II, $\$ 2$, cl. 2 (stating that the President has power, "with the Advice and Consent of the Senate, to make Treaties, provided two thirds of the Senators present concur”), and id. at art. I, $\S 8$, cl. 10 (authorizing a national institution, Congress, "[t]o define and punish ... Offenses against the Law of Nations"), with $i d$. at art. I, $\S 10$, cls. 1-2 (banning states from making treaties, alliances, agreements, or compacts with foreign powers without the consent of Congress; prohibiting states from engaging in war unless actually invaded; and forbidding them from laying imposts or duties on imports or exports without the consent of Congress).

${ }^{44}$ Jessup, supra note 15 , at 741-43 (noting that the several states of the Union are entities unknown to international law). But see infra notes 207, 210 and accompanying text (discussing the limited ways in which subnational governments in the United States and Germany have participated in international agreements and regional arrangements).

See supra notes 14-15 (citing examples of Supreme Court opinions supporting the "one voice" approach to foreign affairs); see also United States v. Pink, 315 U.S. 203, 232 (1942) ("If state action could defeat or alter our foreign policy, serious consequences might ensue. The nation as a whole would be held to answer if a [s] tate created difficulties with a foreign power.").

${ }^{46}$ Koh, supra note 10, at 1825; see also id. at $1825 \mathrm{n} .4$ (citing complaints by "[b] oth Edmund Randolph and James Madison . . . at the Constitutional Convention about the Continental Congress's inability to give effect to the law of nations under the Articles of Confederation"); MARKs, supra note 42, at 145 ("The lesson was clear: there was need for a strong national executive, and such an office would prove effective."); RAKOVE, supra note 32, at 29 ("[A]s most proposals to amend the Articles sought to free Congress from its debilitating dependence on the states, the agenda of national reform seemed designed to reduce rather than strengthen the connections between state and national politics."); 1 THE RECORDS OF THE FEDERAL CONVENTION OF 1787, at 24-25, 316-17 (Max Farrand ed., 1966) (noting the inability of the Articles of Confederation to control State relations with foreign nations). 
In the judicial context, while some judges in the United States are deeply engaged with international law, ${ }^{47}$ most judges are reluctant to apply these norms. ${ }^{48}$ This is the case even though ratified human rights treaties and customary international law are both law of the land in the United States." Under the Supremacy Clause, the law of the land is binding on the federal governments as well as on state and local governments. ${ }^{500}$ Even so, some judges dismiss the relevance of international law claims or are openly hostile to them. ${ }^{51}$ While ratified

${ }^{47}$ See, e.g., Breard v. Pruett, 134 F.3d 615 (4th Cir. 1998) (affirming district court's denial of federal habeas relief to petitioner raising procedurally barred Vienna Convention claim), cert. denied sub nom., Breard v. Greene, 523 U.S. 371, 380 (1998) (Breyer, J., dissenting from denial of certiorari) (finding foreign national's argument for stay of execution not wholly without merit where the United States submitted an amicus brief acknowledging that the Vienna Convention on Consular Relations, done Apr. 24, 1963, art. 42, 21 U.S.T. 77, 104, 596 U.N.T.S. 261, 296, had been violated because the foreign national was not notified of his right to communicate with his consulate); Ruth Bader Ginsburg \& Deborah Jones Merritt, Fifty-First Cardozo Memorial Lecture: Affirmative Action: An International Human Rights Dialogue, 21 CARDOZO L. REV. 253, 281-82 (1999) (reflecting Justice Ginsburg's awareness of the relevance of international human rights law domestically); see also Thompson v. Oklahoma, 487 U.S. 815, 830-31 (1988) (Stevens, J.) (relying on the laws of other nations in interpreting the Eighth Amendment in a juvenile death penalty case involving a fifteen-year-old); MARY L. DUDZIAK, COLD WAR CIVIL RIGHTS 90-102 (2000) (highlighting evidence that in the $1950 \mathrm{~s}$, the Supreme Court may have been swayed by arguments in the Justice Department's briefs indicating that segregation threatened the role of the United States as a global leader for democracy).

48 See Eyal Benvenisti, Judicial Misgivings Regarding the Application of International Law: An Analysis of Attitudes of National Courts, 4 EUR. J. INT'L L. 159, 160-75 (1993) (discussing reasons that prompt most national courts to approach international norms apprehensively and limit their application within national legal systems).

${ }^{49}$ Henkin, supra note 10, at 1565; see also In re Paquete Habana, 175 U.S. 677, 700 (1900) ("International law is part of our law, and must be ascertained and administered by the courts ... as often as questions of right depending upon it are duly presented for their determination.").

51) U.S. ConsT. art. VI, § 1, cl. 2 ("This Constitution, and the Laws of the United States which shall be made in Pursuance thereof; and all Treaties made, or which shall be made, under the Authority of the United States, shall be the supreme Law of the Land ....").

See, e.g., Greene, 523 U.S. at 374 (denying certiorari and motion for stay of execution in spite of an International Court of Justice opinion granting a provisional order in a case alleging a violation of the Vienna Convention on Consular Relations); Federal Republic of Germany v. United States, 526 U.S. 111, 111-12 (1999) (same); Thompson, 487 U.S. at 869 n.4 (Scalia, J., dissenting) (arguing that laws of other nations have little relevance to interpreting Eighth Amendment standards of cruel and unusual punishment in the context of executions of fifteen-year-olds, stating that "it is a Constitution for the United States of America that we are expounding"); see also Stanford v. Kentucky, 492 U.S. 361, 369 n.1 (1989) (Scalia, J.) (rejecting the relevance of the law of other nations in interpreting the Eighth Amendment in a juvenile death penalty case involving sixteen- and seventeen-year-olds and stating that " $[\mathrm{w}] \mathrm{e}$ emphasize that it 
treaties and customary international law are "our law, bers of the Supreme Court view international human rights law as an offshore body of law-an alien set of norms that exists out "there," overseas, but have little relevance "here," in the United States. "Missing from this approach is recognition of how international law got "there," as well as the role Americans played in putting it "there."

A further constraint in the judicial context is the fact that the United States has neither ratified several of the major human rights treaties, ${ }^{55}$ nor fully implemented treaties that it has ratified. Having declared most human rights treaties it ratifies to be non-selfexecuting, the United States has limited the enforceability of these treaties absent implementing legislation. ${ }^{56}$ By not enacting implemen-

is American conceptions of decency that are dispositive").

${ }_{52}$ Paquete Habana, 175 U.S. at 700.

${ }^{53}$ See Knop, supra note 21, at 522-23 (using the "here" and "there" distinction to demonstrate the perceived distance between national and international law); see also LOUIS HENKIN, THE AGE OF RIGHTS 157-78 (1989) (using the "here" and "there" distinction to demonstrate the perceived distance between U.S. law and the law of other countries). Compare supra note 47 (citing cases in which Supreme Court Justices recognized the relevance of international law to interpreting U.S. constitutional claims), with supra note 51 (citing cases in which Supreme Court Justices failed to recognize the relevance of international law in interpreting U.S. constitutional claims).

${ }^{54}$ For discussions of the role Americans played in developing and sustaining the international human rights framework, see MARY ANN GLENDON, A WORLD MADE NEW: ELEANOR ROOSEVELT AND THE UNIVERSAL DECLARATION OF HUMAN RIGHTS (2001); and President Roosevelt's "Four Freedoms" speech, Franklin D. Roosevelt, Annual Message to Congress (Jan. 6, 1941), in 9 THE Public PAPERS AND ADDREsSES OF FRANKLIN D. ROOSEVELT, 1940, at 663 (1941), which paved the way for critical concepts in the Universal Declaration of Human Rights. See also HENKIN, supra note 53, at 156 ("American constitutionalism can proudly claim an important part in the development of international human rights, and in their dissemination to every continent and corner."); Oscar Schacter, International Law Implications of U.S. Human Rights Policies, 24 N.Y.L. SCH. L. REv. 63, 66-69 (1978) (discussing how the United States has given impetus to recognition of core human rights as international legal obligations even in the absence of human rights treaties).

${ }^{55}$ For example, the United States has signed but not ratified, inter alia, CEDAW, supra note 3; Convention on the Rights of the Child, opened for signature Nov. 20, 1989, 1577 U.N.T.S. 44; and International Covenant on Economic, Social and Cultural Rights, opened for signature Dec. 16, 1966, S. EXEC. Doc. D, 95-2, at 13, 993 U.N.T.S. 4.

${ }_{56}$ Debates regarding the validity and impact of non-self-executing declarations remain. Compare LOUIS HENkIN, FOREIGN AFFAIRS AND THE UNITED STATES CONSTITUTION 201-02 (2d ed. 1996) (arguing that the use of non-self-executing declarations is "'anti-Constitutional' in spirit and highly problematic as a matter of law"), Lori F. Damrosch, The Role of the United States Senate Concerning "Self-Executing" and "NonSelf-Executing" Treaties, 67 CHI.-KENT L. REV. 515, 532 (1991) (questioning whether nonself-executing declarations have either domestic or international effect), Martin S. Flaherty, History Right?: Historical Scholarship, Original Understanding, and Treaties as "Supreme Law of the Land", 99 COLUM. L. REV. 2095, 2097-99 (1999) (supporting the doc- 
tating legislation where existing measures are absent and by not taking other steps to achieve the substantive rights in ratified treaties, the United States fails to follow through on international obligations that require treaty signatories to implement these instruments through legislation and other measures. ${ }^{57}$

The reluctance and open hostility some federal courts express toward international law claims reflect ambivalence toward the legitimacy of international law as a source of law. While expert organizations such as Amnesty and Human Rights Watch (along with a small handful of law school-based human rights clinics) file amicus briefs introducing courts to these claims, most courts refuse to view international law claims as relevant to the resolution of specific cases. Because international law is not claimed by the American people as "our law," some judges argue that we can legitimately ignore it. By contrast, if Americans adopted international standards as their standards, then an analysis of international law would indeed be relevant to determining, for example, "evolving standards of decency" in the context of the Eighth Amendment's prohibition on cruel and unusual punishment. ${ }^{5 *}$ While adoption of international law as "our law" rarely

trine of self-executing declarations in response to John Yoo), and Carlos Manuel Vazquez, The Four Doctrines of Self-Executing Treaties, 89 AM. J. INT'L. L. 695, 700-22 (1995) (identifying four legitimate reasons for concluding that a treaty is non-self-executing), with John C. Yoo, Globalism and the Constitution: Treaties, Non-Self-Execution, and the Original Understanding, 99 Colum. L. REv. 1955, 1961-62(1999) [hereinafter Yoo, Globalism and the Constitution] (challenging the view that the Founders intended treaties to be self-executing), and John C. Yoo, Treaties and Public Lawmaking: A Textual and Structural Defense of Non-Self-Execution, 99 COLUM. L. REV. 2218, 2221-33 (1999) [hereinafter Yoo, Treaties and Public Lawmaking] (replying to Flaherty's response to Yoo's earlier article defending non-self-execution).

${ }_{57}$ See, e.g., ICCPR, supra note 5, at art. 2, para. 2, S. EXEC. DOC. E, 95-2, at 24, 999 U.N.T.S. at 173-74 (“[E] ach State Party to the present Covenant undertakes to take the necessary steps, in accordance with its constitutional processes and with the provisions of the present Covenant, to adopt such legislative or other measures as may be necessary to give effect to the rights recognized in the present Covenant."); $i d$. at art. 2, para. 3, S. EXEC. Doc. E, 95-2, at 24, 999 U.N.T.S. at 173-74 ("Each State Party to the present Covenant undertakes: (a) To ensure that any person whose rights or freedoms as herein recognized are violated shall have an effective remedy...."); see also Convention Against Torture and Other Cruel, Inhuman or Degrading Treatment or Punishment, opened for signature Dec. 10, 1984, arts. 4-5, S. TREATY DOC. NO. 100-20, at 20, 1465 U.N.T.S. 113, 114 (using similar language, but including requirement that each State Party "ensure that all acts of torture are offences under its criminal law").

${ }^{58}$ Compare Stanford v. Kentucky, 492 U.S. 361, 369 \& n.1 (1989) (Scalia, J.) (finding that the laws of other nations have little relevance to interpreting the Eighth Amendment prohibition on cruel and unusual punishment in the context of executions of people who were sixteen or seventeen years old at the time of the offense because "it is American conceptions of decency that are dispositive"), with Thompson v. 
occurs in federal courtrooms, outside the courtroom international human rights law is increasingly shaping debates at the state and local levels in the context of the death penalty.

In the legislative and executive branches of government, the current practice of adopting treaties involves what I call a "black box" approach whose reliance on technical expertise in human rights allows, at best, modest engagement by members of the citizenry beyond Washington-based, inside-the-beltway nongovernmental organizations (NGOs). ${ }^{59}$ By short-circuiting broad-based deliberation, this "black box" approach allows "transmittal of the international," not a full "process of translation from international to national." the federal government's failure to engage in this process of translation-in its neglect of international law as either an interpretive tool or as binding law-most Americans see international human rights law as an irrelevant offshore body of law. ${ }^{61}$ This Article argues that a more complete drawing down of international law depends on the development of more participatory mechanisms through which Americans can foster a deeper human rights culture. ${ }^{62}$ By cultivating and amplifying the voices of state and local governments in the adoption and implementation of human rights, dialogic federalism assists in widening the base of support for and increasing the legitimacy of these

Oklahoma, 487 U.S. 815, 830-31 (1988) (Stevens, J.) (finding that the laws of other nations were relevant in interpreting the Eighth Amendment in a case concerning the execution of a person who was fifteen years old at the time the offense was committed).

Cf. Oliver Gerstenberg \& Charles F. Sabel, Directly-Deliberative Polyarchy: An Institutional Ideal for Europe?, at 2, at http://www.law.columbia.edu/sabel/papers.htm (last visited Nov. 26, 2001) (discussing how a similar dynamic is at work in the European Union, where "the sheer complexity [of the emerging system] and especially its reliance on technocratic deliberation, renders implausible even the most modest assumption of effective political oversight by an informed citizenry").

${ }^{60}$ Knop, supra note 21, at 505 (emphasis added).

${ }^{61}$ Cf. Dorothy Q. Thomas, Advancing Rights Protection in the United States: An Internationalized Advocacy Strategy, 9 HARV. HUM. RTS. J. 15, 19 (1996) (describing evidence that "domestic rights groups in the United States have become less, rather than more, internationalized in their advocacy approach," and attributing this to "the U.S. government's longstanding determination to insulate the national legal system from the influence of international law").

${ }^{62}$ Karen Knop refers to this sentiment as Völkerrechtsfreundlich-“"friendly to international law." Knop, supra note 21, at 502 (using this term loosely and citing, for the more technical meaning, Brunno Simma et al., The Role of German Courts in the Enforcement of International Human Rights, in ENFORCING INTERNATIONAL HUMAN RIGHTS IN DOMESTIC COURTS 71, 94-96 (Benedetto Conforti \& Francesco Francioni eds., 1997)). Of course, there is a chicken-and-egg problem here in that dialogic federalism both creates and requires a deeper human rights culture. 
6.3

norms.

Rather than mobilize support for meaningful ratification of these treaties by convincing the public that treaty commitments will make a difference in their lives, the Washington-based NGO insiders reassure lawmakers that adoption of human rights treaties will not fundamentally disturb existing domestic law commitments. These reassurances become self-fulfilling in that lawmakers attach a range of conditions known as reservations, understandings, and declarations (RUDs) to treaties to ensure that their impact is limited. ${ }^{64}$ RUDs, in turn, reinforce the lack of domestic constituent support for treaties adopted by stealth within the black box, since there appears to be little value added. However, without such conditions attached, human rights treaties could dramatically expand protections for disenfranchised individuals. ${ }^{6.5}$ These stealth treaties slip silently into law, encumbered with RUDs that water down their domestic impact. Not surprisingly, the perception that follows is that these treaties are ineffective, dead letters of the law, ensuring continued apathy for the human rights norms that these treaties convey.

${ }^{63}$ Of course, broadening participation in the deliberation and implementation of human rights law does not necessarily ensure that the public will accept these norms. After all, knowledge does not equal acceptance. However, this Article argues that it is better to have fewer international human rights norms incorporated into domestic law that enjoy broader support and legitimacy than to have many international norms formally incorporated that lack de facto legitimacy.

${ }^{64}$ These RUDs frequently include, for example, a boiler-plate declaration pronouncing that a treaty is non-self-executing, as described above. For further discussion of RUDs, see Louis Henkin, U.S. Ratification of Human Rights Conventions: The Ghost of Senator Bricker, 89 AM. J. INT'L L. 341, 349 (1995), explaining that U.S. RUDs upholding federalist ideals limit the impact of treaties and agreements; $a \rightarrow$ Curtis A. Bradley \& Jack L. Goldsmith, Treaties, Human Rights, and Conditional Consent, 149 U. PA. L. REV. 399,419 (2000), explaining that non-self-executing "declarations are designed to preclude the treaties from being enforceable in U.S. courts in the absence of implementing legislation."

Even with RUDs, including non-self-executing declarations, treaties may provide some value. See Martha F. Davis, International Human Rights and United States Law: Predictions of a Courtwatcher, 64 ALB. L. REV. 417, 428-36 (2000) (demonstrating the value of international human rights law as interpretive tool); Connie de la Vega, Civil Rights During the 1990s: New Treaty Law Could Help Immensely, 65 U. CIN. L. REv. 423, 467-70 (1997) (proposing that government entities can use non-self-executing treaties to defend programs that protect or promote the human rights goals of the treaties); see also Murray v. Schooner Charming Betsy, 6 U.S. (2 Cranch) 64, 118 (1804) (offering a canon of statutory construction that directs that "an act of [C] ongress ought never to be construed to violate the law of nations if any other possible construction remains"); Ralph G. Steinhardt, The Role of International Law as a Canon of Domestic Statutory Construction, 43 VAND. L. REV. 1103 (1990) (suggesting ways to use the Charming Betsy principle as an interpretive tool). 
Scholars who follow the revisionist/fragmentation model may argue that RUDs represent resistance by domestic constituencies to efforts by international elites that would disrupt local practices, and that in this sense, RUDs reflect democracy at work. In fact, this is what Senator Bricker and other segregationists argued for in trying to limit the reach of the treaty power in the $1950 \mathrm{~s} .{ }^{66}$ However, there is no evidence today that RUDs mark an attempt to preserve local practices. Because ratification occurs with the advice and consent of the Senate, and not the House, it is hard to argue that RUDs truly reflect local practices.

Rather, the adoption and compliance of human rights treaties by stealth paves the way for limited and cramped incorporation of international protections with conditions that restrict the reach of these instruments. Stealth treaties are also troubling because they result in the average person on the street having little to no knowledge of the international human rights protections to which she is entitled. Clearly there is a paradox if the only way to ensure that the executive branch and Senate adopt treaties is by stealth, which in turn ensures that treaties are ineffective, dead letters of the law.

\section{DiALOGIC FEDERALISM}

To move beyond these challenges, this Article proposes dialogic federalism as a possible solution. Rather than embrace zero-sum understandings of the respective roles of federal and nonfederal systems, a dialogic approach depends on cooperation between these systems to translate broad international law principles into concrete domestic laws and policies. Borrowing insights from both the revisionist/fragmentation and traditional/hierarchical models described above, dialogic federalism seeks to both (1) deepen the democratic legitimacy of international human rights laws through state and local innovation in implementing these laws, and (2) broaden forms of national coordination of this innovation.

Achieving these twin goals involves bridging the two visions of the Constitution alluded to above: ${ }^{67}$ its commitment to complex divisions of powers (in accord with its Madisonian inspiration) on the one hand, and its stake in national institutions designed to address the in-

66 See Natalie Hevener Kaufman, Human Rights Treaties and the Senate: A HISTORY OF OPPOSITION 99-100, 108-10 (1990) (describing how the Bricker Amendment would have protected states' rights in the context of treaty ratification).

${ }^{67}$ Supra notes 29-32 and accompanying text. 
ability of the Continental Congress to give effect to the law of nations under the Articles of Confederation, on the other hand. The latter vision was bolstered by federal initiatives of the New Deal and civil rights eras. By arguing for ways to afford citizens and other actors greater participation in using local knowledge to craft solutions that fit the particular circumstances of their communities, ${ }^{68}$ democratic experimentalists have tried to theorize new forms of governance that accommodate the essence of these two visions. The tension between these two visions is reflected in the society's erratic jurisprudence on federalism, which prohibits Congress from commandeering states even while it permits Congress to deeply influence state lawmaking through constitutional spending powers and conditional preemption. $^{699}$ Democratic experimentalists propose to resolve this dilemma by enabling state and local governments to partner with (rather than replace) federal government in more meaningful ways by facilitating more participatory and democratic modes of lawmaking.

Similarly, dialogic federalism envisions intergovernmental cooperation and dialogue as a means of addressing this constitutional conundrum and democratizing the implementation of human rights law in the United States. This approach "reinterprets democratic deliberation to advance the Madisonian project of using the institutions of government itself to foster practical cooperation." ${ }^{, 70}$ It is in this spirit that a dialogic approach is offered "not as an alternative to the American constitutional tradition but as an interpretation of it." As an interpretation of this tradition, dialogic federalism acknowledges the federal government's foreign affairs role provided under the U.S. Constitution and anticipated by international law. ${ }^{72}$ This model also recognizes the risk of "multiple variants of the same international law rule $^{\text {"73 }}$ that the establishment of a national constitution was designed to avoid.

However, the rationale behind the need for the nation to speak

${ }^{68}$ See, e.g., Dorf \& Sabel, supra note 29, at 314, 316-23 (presenting the basic features of a "subnational, pragmatist government").

69) See id. at 419-28 (“[T] he Supreme Court oscillates ... between revisionary revivals of the distinction [between federal and state powers] and weary criticism of the revision.").

${ }^{70} I d$. at 289.

${ }^{71} I d$.

${ }^{72}$ See supra notes $43-44$ and accompanying text (describing authority for the federal government's role under the U.S. Constitution and international law, respectively).

Koh, supra note 10, at 1832. 
with "one voice" through the President with respect to other countries-that is, to avoid sending contradictory signals regarding U.S. relations with other countries-loses its bite in the context of domestic incorporation of international human rights law. ${ }^{74}$ In the foreign affairs context, contradictory signals may be sent if, for example, a state or local government imposes sanctions on a foreign country that are inconsistent with federal policy toward that country. Thus, in Crosby $v$. National Foreign Trade Council, the Supreme Court held that a Massachusetts sanctions law regarding Burma was preempted by federal legislation directing the President to develop "a comprehensive, multilateral strategy to bring democracy to and improve human rights practices and the quality of life in Burma. ${ }^{75}$ In the context of domestic incorporation of international human rights law, the risk of sending contradicting signals in U.S. relations with other countries is significantly less. Yet, a subnational approach to domestic incorporation of human rights may lead to the development of "divergent and perhaps parochial state interpretations" ${ }^{\prime 76}$ of international standards, which the Founders sought to avoid. ${ }^{77}$ Moreover, since the parameters of foreign and domestic are often intermingled, ${ }^{78}$ there is an outside chance that such pronouncements could affect U.S. relations with other countries in ways that would obscure "the President's power to speak and bargain effectively with other nations." ${ }^{79}$ A possible way to

${ }^{74}$ For a classic statement of the rationale behind the "one-voice" principle, see Crosby v. National Foreign Trade Council, 530 U.S. 363, 381 (2000), stating, "[t]he President's maximum power to persuade [in foreign affairs] rests on his capacity to bargain for the benefits of access to the entire national economy without exception for enclaves fenced off willy-nilly by inconsistent political tactics." Id.

Id . at 369 (quoting Omnibus Consolidated Appropriations Act, Pub. L. No. 104208, §570(c), 110 Stat. 3009, 3009-166 (1997)).

${ }_{77}^{76}$ Banco Nacional de Cuba v. Sabbatino, 376 U.S. 398, 425 (1964).

${ }^{77}$ See supra note 42 (discussing the Founders' opinions about American foreign policy).

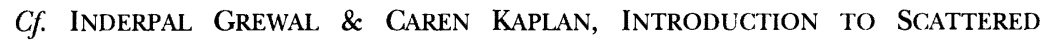
Hegemonies: POSTMOdernity and TRANSNATIONAL Feminist PraCtices 10-13 (Inderpal Grewal \& Caren Kaplan eds., 1994) (discussing blurring of the line between global and local).

${ }^{79}$ Crosby, 530 U.S. at 382 . For example, a state government's narrow interpretation of the scope of international law obligations in the death penalty context can implicate and has implicated the nation's relations with other countries. See, e.g., LaGrand Case (F.R.G.v. U.S.), 2001 I.C.J. No. 104 (June 27) (holding that Arizona failed to notify two German nationals facing the death penalty of their rights under the Vienna Convention on Consular Relations, which requires notifying an arrested or detained foreign national of his right to consult with a consular official, in a case brought by Germany against the United States to challenge the death sentences), available at http://www.icj-cji.org; Case Concerning the Vienna Convention on Consular Relations 
limit this risk is by preempting state and local government attempts to convert their incorporation of international human rights laws into pronouncements of international law. Under this approach these state and local enactments would operate as nothing more than state and local law, adopted pursuant to authority that clearly exists at the subnational level.

In fact, enabling state and local governments to partner with the federal government in incorporation of human rights law may convert weakly-legitimated norms developed at the international level into norms that are more strongly legitimated at a local level. By bringing human rights lawmaking closer to the people whose rights are affected, a dialogic federalist approach has the added benefit of democratizing the implementation of international law norms. Furthermore, incentivizing state and local governments to experiment with the direct incorporation of human rights law would address, to a large extent, the federalism concerns raised in the context of federal incorporation of norms perceived as falling within areas traditionally relegated to states such as family law and criminal law.

These federalism concerns are raised even though, according to the Supreme Court in Missouri $v$. Holland, the treaty power authorizes Congress to legislate under the Necessary and Proper Clause ${ }^{81}$ in areas beyond those specifically conferred on Congress by Article I, Section 8 of the Constitution, and the treaty power is not subject to most Tenth Amendment limitations. ${ }^{82}$ The proposed Bricker Amendment in the 1950 s would have formally limited the treaty power to the extent it ex-

(Para. v. U.S.), 1998 I.C.J. No. 99 (Nov. 10) (holding that because the state of Virginia failed to notify a Paraguayan national facing the death penalty of his right to consult a consular official, the United States violated the Vienna Convention on Consular Relations, in a case brought by Paraguay against the United States to challenge the death sentence), available at http://www.icj-cji.org.

${ }^{81)}$ But see Dorf \& Sabel, supra note 29, at 419-28 (suggesting that the Supreme Court's jurisprudence on federalism is misguided); Resnik, supra note 17 (manuscript at 3) (arguing that we need to be less categorical about what we view as "truly local" and "truly national"); Reva Siegel, She, the People: The Nineteenth Amendment, Sex Equality, Federalism, and the Family, 115 HARV. L. REV. (forthcoming 2002) (arguing that the Nineteenth Amendment could be read as subverting traditional understandings of family, women's roles in the family, gender equality, and federalism).

${ }^{81}$ U.S. CONST. art. I, \$ 8, cl. 18.

${ }^{82} 252$ U.S. 416, 434 (1920) ("No doubt the great body of private relations usually fall within the control of [a] [s] tate, but a treaty may override its power."). While Missouri $v$. Holland holds that most Tenth Amendment limitations do not apply to the treaty power, it is less clear whether the anticommandeering doctrine, which prohibits Congress from conscripting state legislators or officers to enforce federal law, applies to the treaty power. 
tends congressional authority beyond the constraints of federalism. ${ }^{83}$ Despite the 1954 defeat of the Bricker Amendment, the current practice by the Senate and executive branch of attaching federalism understandings ${ }^{84}$ and other conditions to treaties during the ratification process achieves the same result. ${ }^{85}$ Arguably, a federalism understanding "'serve[s] no legal purpose," because "such a declaration of intent does not decrease the United States' international obligations and does not decrease in the slightest the power of Congress to implement those obligations., ${ }^{\$ 66}$ However, in light of the Supreme Court's new

${ }^{83}$ See KAUfMAN, supra note 66, at 99-100, 108-10 (describing how the Bricker Amendment would have protected states' rights in the context of treaty ratification).

${ }^{84}$ For example, see the U.S. RUDs to the ICCPR:

That the United States understands that this Covenant shall be implemented by the Federal Government to the extent that it exercises legislative and judicial jurisdiction over the matters covered therein, and otherwise by the state and local governments; to the extent that state and local governments exercise jurisdiction over such matters, the Federal Government shall take measures appropriate to the Federal system to the end that the competent authorities of the state or local governments may take appropriate measures for the full fulfillment of the Covenant.

U.S. RUDs to the ICCPR, supra note 5, at 8071.

Professor Gerald Neuman observes, "The legislative history explains that an understanding rather than a reservation was employed, because 'the intent is not to modify or limit U.S. undertakings under the Covenant but rather to put our future treaty partners on notice with regard to the implications of our federal system concerning implementation." Gerald L. Neuman, The Global Dimension of RFRA, 14 CONST. COMMENT. 33, 51-52 (1997) (quoting S. EXEC. REP. No. 102-23, at 18 (1992) (reprinting the George H.W. Bush administration's explanation)).

While a federalism understanding represents a fairly explicit demonstration of federalism concerns, a more implicit way the U.S. expresses these concerns is by entering a reservation on a treaty provision concerning a right that traditionally falls within the ambit of state regulation. See, e.g., U.S. RUDs to the ICCPR, supra note 5, at 8070 (providing a U.S. reservation on the provision prohibiting the juvenile death penalty).

${ }^{8: 5}$ See DuANe TaNANBaum, The Bricker AMENDMENT CONTROVERSY: A TeST OF EISENHOWER'S POLITICAL LEADERSHIP 89 (1988) (discussing Eisenhower's promise to exercise treaty-making power only within "traditional limits," consistent with the Bricker Amendment); Henkin, supra note 64, at 349 (explaining that the Senate and executive branch's current practice of attaching RUDs to treaties achieves the goal Senator Bricker sought).

${ }^{86}$ Neuman, supra note 84 , at 52 (quoting Henkin, supra note 64 , at 346 ). Note that Professor Neuman is making two distinct points here regarding the impact of a federalism understanding: one international and the other domestic. The first point concerns the impact on the United States' international obligations, while the second concerns the impact on its domestic authority to implement those obligations. On the domestic point, Professor Spiro comes to a different conclusion. See Spiro, supra note 17, at 576-77 (arguing that "federalism understandings constitute a formal institutional statement of law"). Professor Spiro notes:

Indeed, the pattern of a defeated amendment followed by a practice consistent with the amendment's substance bears some resemblance to Bruce Ack- 
federalism jurisprudence, ${ }^{87}$ Congress may be hesitant to regulate conduct deemed to be quintessentially local in nature (such as criminal and family law) ${ }^{88}$ At the very least, at the domestic level, a federalism understanding represents a political gesture to reassure state and local governments that the federal government will not use the treaty in question to disturb existing divisions of power between national and subnational units. ${ }^{89}$ At the international level, the United States often points to deference to states' rights as the reason why it cannot meet international human rights requirements. ${ }^{90}$ In fact, it is not clear whether the federal government can impose these requirements on state and local governments through federal directives without violating the anti-commandeering doctrine, which prohibits the federal government from issuing such directives. ${ }^{91}$ Thus, supporting state and local governments to participate in domestic implementation of hu-

erman's and David Golove's description of how the congressional-executive agreement came to win constitutional legitimacy outside of the Article II treaty process. ... In both episodes, proposed amendments were defeated in part because of informal institutional agreement to respect their substance.

Id. at 576 n.32 (citing Bruce Ackerman \& David Golove, Is Nafta Constitutional?, 108 HARV. L. REV. 799 (1995)). On the international point, Spiro agrees with Neuman that federalism understandings lack international effect. Id. at 577; see also ICCPR, supra note 5, at art. 50, S. EXEC. Doc. E, 95-2, at 38, 999 U.N.T.S. at 185, which applies to "all parts of federal States without any limitations or exceptions."

${ }^{87}$ See, e.g., Printz v. United States, 521 U.S. 898, 935 (1997) (holding that the federal government may not compel the states "to administer or enforce a federal regulatory program"); U.S. v. Lopez, 514 U.S. 549, 549 (1995) (finding that a federal gun control law banning firearm possession in local school zones exceeds Congress' Commerce Clause power); New York v. United States, 505 U.S. 144, 149 (1992) (holding that Congress may not commandeer the states' legislative processes by directly compelling states to enact and enforce a federal regulatory program). But see Bush v. Gore, 531 U.S. 98, 104 (2000) (reversing the Florida Supreme Court on an issue of state law).

${ }^{88}$ See United States v. Morrison, 529 U.S. 598, 598-99 (2000) (striking down the "civil rights remedy" provision in the Violence Against Women Act as unconstitutional, holding that Congress lacked the authority to regulate the sphere reserved for the states). For a critique of the Supreme Court's decision in United States v. Morrison, see Resnik, supra note 17.

${ }^{89}$ Neuman, supra note 84 , at 52-53 ("The federalism understanding does, however, signal the political reality that some members of Congress are reluctant to exercise existing federal power [to enforce treaties] in areas of traditional state regulation.”).

See, e.g., U.N. GAOR, Hum. Rts. Comm., 53rd Sess., 1405th mtg. II 12-13, U.N. Doc. CCPR/C/SR.1405 (1995) (“[T]he decision to retain [the death penalty] reflected a serious and considered democratic choice of the American public.... [The juvenile death penalty was retained because a] large majority of states permitted juveniles to be tried as adults in grave cases involving capital offences at . . 16 or 17.")

${ }^{91}$ See supra notes 82,87 (explaining anticommandeering doctrine and cases, respectively). 
man rights would clear the way for compliance at the federal level, as state and local noncompliance would no longer justify federal noncompliance based on federalism concerns.

Facilitating state and local involvement in implementing human rights standards may also address democratic deficits inherent in the making and implementation of international law at the national level. Because the international system is a system of states, national governments-not individuals-participate in the development and adoption of international norms. While NGOs are increasingly gaining a voice in treaty-making arenas and other fora where important international law decisions are made, access to these decision-making processes is often mediated by elaborate credential requirements that limit participation. ${ }^{92}$

Additionally, as discussed above, the general public is disengaged from the primary processes through which human rights law is incorporated at the national level. As the work of democratic experimentalists and other scholars suggests, similar democratic deficits are reflected in the formation of domestic legislation in the United States, as well as in other contexts including the European Union. ${ }^{94}$ The omission of the House from the treaty-ratification process is a factor that may undermine further the democratic legitimacy of international human rights treaty law. Subnational participation in incorporating human rights laws strengthens democratic deliberation of these laws.

Participation by subnational governments and NGOs in incorporating human rights law can usefully be considered in the context of

92 Cf. Eyal Benvenisti, Exit and Voice in the Age of Globalization, 98 MiCH. L. REV. 167, $170,202-11$ (1999) (proposing a theory of transnational institutions that could offer "more effective opportunities for democratic participation in national and transnational decision making").

93 See, e.g., MASHAW, supra note 28, at 100-01 (highlighting an interpretation of public choice analysis of legislative organization in which committee members who are unrepresentative of the Congress as a whole, and thus likely unrepresentative of the people as a whole, dominate the legislative process); Dorf \& Sabel, supra note 29, at 270-92 (proposing as a solution "democratic experimentalism" which combines federal learning with the protection of the federated jurisdictions and the rights of individuals); Tushnet, supra note 38, at 1069-71 (discussing the democratic deficit inherent in national politics in the U.S. and suggesting that general cultural transformation, rather than the revival of constitutional federalism, may be the way to eliminate such a deficit).

${ }^{94}$ See Gerstenberg \& Sabel, supra note 59, at 2-5 (noting that the complexity of multilevel governance in the European Union "renders implausible even the most modest assumption of effective political oversight by an informed citizenry"). 
the "disaggregation" of sovereignty, ${ }^{95}$ the permeability of national borders, and the ascendancy of a transnational civil society. ${ }^{96}$ Interestingly, the theory that the State is disaggregating concludes that the formation of transnational networks between and among government bureaucrats and judges within these States leads to greater convergence and harmonization, not less. ${ }^{97}$ Conceivably, intranational networks of NGOs and/or state and local governments may lead to a similar convergence of norms. ${ }^{9.8}$ At the same time, these local enactments might be read as facilitating public policy experimentation. More diffuse modes of implementing human rights law at various levels of government are consistent with what other scholars have described as the

See Anne-Marie Slaughter, International Law in a World of Liberal States, 6 EUR. J. INT'L L. 503, 505, 537 (1995) [hereinafter Slaughter, International Law] (envisioning "a world of liberal States," in which the State and sovereignty are disaggregated into "component political institutions"); see also SASKIA SASSEN, GLOBALIZATION AND ITS DisCONTENTS 92 (1998) ("[T] here is an unbundling of sovereignty[:] . . . the relocation of various components of sovereignty onto supranational, nongovernmental, or private institutions."); Anne-Marie Slaughter, The Real New World Order, FoREIGN AFF., Sept./Oct. 1997, at 183, 184 ("The [S] tate is not disappearing, it is disaggregating into its separate, functionally distinct parts. These parts ... are networking with their counterparts abroad, creating a dense web of relations that constitutes a new, transgovernmental order."); Peter J. Spiro, Foreign Relations Federalism, 70 U. Colo. L. REV. 1223 (1999) (extending Professor Slaughter's disaggregation thesis to include disaggregation of federal and subfederal actors).

!fi See Tadashi Yamamoto \& Jessica T. Mathews, Foreword to THE THIRD FORCE: The RiSE OF TRANSNATIONAL CIVIL SOCIETY, at vi (Ann M. Florini ed., 2000) (arguing that the "border-spanning networks" that comprise transnational civil society "are a real and enduring force in the international relations of the twenty-first century"); see also ABram Chayes \& ANTONia HANDler ChaYes, THE NEW SOVEREIGNTY: COMPLIANCE WITH INTERNATIONAL REGULATORY AGREEMENTS 27 (1995) ("[E]ven [the largest and most powerful States] cannot achieve their principal purposes ... without the help and cooperation of many other participants in the system, including entities that are not [S] tates at all."); MARGARET E. KECK \& KATHRYN SikKINK, ACTIVISTS BEyOND Borders: AdVOCACY NETWORKS IN INTERNATIONAL POLITICS 3-5 (1998) (describing transnational advocacy networks as communication structures that use information strategically " $[\mathrm{t}]$ o influence discourse, procedures, and policy" on an international scale); Benvenisti, supra note 92, at 169 (advocating a "transnational conflict paradigm" that "shows how domestic interest groups often cooperate with similarly situated foreign interest groups in order to impose externalities on rival domestic groups"); Harold Hongju Koh, The 1998 Frankel Lecture: Bringing International Law Home, 35 HoUs. L. REV. 623, 647-48 (1998) (describing the role of transnational norm entrepreneurs, i.e., those who assist States to internalize norms in the transnational legal process).

See Slaughter, International Law, supra note 95, at 512-13 (discussing the correlation between a high level of transnational networks and a convergence in the reluctance to use force among liberal democracies).

See Spiro, supra note 95, at 1267 ("Retaliation at the international level is increasingly governed by norms rather than merely by interests, and indeed is now being undertaken by a variety of actors beyond nation-states."). 
emergence and utilization of norm entrepreneurs, who develop transnational networks as communication structures that use information strategically. ${ }^{99}$

At the same time, drawing on the work of democratic experimentalists, ${ }^{100}$ this Article argues that the federal government has an important role to play in coordinating and extracting workable norms from the various local initiatives. There is precedent for the federal government coordinating and encouraging participation of state and local governments in international lawmaking in the trade area, which could provide a possible model. ${ }^{101}$ To avoid the problem of "divergent and perhaps parochial state interpretations" ${ }^{102}$ of the same international law rule, the federal government or other national entity must

99 See KECK \& SIKKINK, supra note 96, at 16, 18-22 (highlighting the ability of transnational advocacy networks "to quickly and credibly generate politically usable information and move it to where it will have the most impact"); see also Benvenisti, supra note 92, at 202-03 (discussing the ability of transnational institutions to reduce informational asymmetries by, inter alia, "monitoring compliance of the various domestic actors" with institutional policies and by "providing access and soliciting input from NGOs representing a variety of interest groups").

${ }^{1001}$ See, e.g., Dorf \& Sabel, supra note 29, at 288 (calling "the overall system of public problem solving that combines federal learning with the protection of the interests of the federated jurisdictions and the rights of individuals democratic experimentalism"); Archon Fung et al., Realizing Labor Standards: How Transparency, Competition, and Sanctions Could Improve Working Conditions Worldwide, BOSTON REV., Feb./Mar. 2001, at http://bostonreview.mit.edu/BR26.1/fung.html (proposing a strategy for strengthening labor standards that would use monitoring and public disclosure of working conditions to create firm-level incentives for improvement); Brad Karkkainen et al., After Backyard Environmentalism: Toward a Performance Based Regime of Environmental Regulation, 44 AM. BEHAV. SCIENTIST 690, 690 (" $[D]$ emocratic experimentalism combines the virtues of localism, decentralization, and direct citizen participation with the discipline of national coordination, transparency, and public accountability." (citation omitted)); Susan Sturm, Second Generation Employment Discrimination: A Structural Approach, 101 COLUM. L. REV. 458, 462-63 (2001) (exploring the potential for a regulatory approach in which "normative elaboration occurs through a fluid, interactive relationship between problem solving and problem definition within specific workplaces and in multiple other arenas, including but not limited to the judiciary").

${ }^{101}$ See George Bermann, Federalism and the Enforceability of United States Treaty Obligations 59 (Jan. 21, 1999) (unpublished manuscript, on file with author). For example, the federal government created an Intergovernmental Policy Advisory Committee (IGPAC) to provide subnational governmental input into international trade negotiations in response to the requirement under the 1974 Trade Act that the President seek advice from the "non-federal" government sector. Id. Approximately thirty to forty state and local government officials, including governors, participate in the IGPAC. Id. at 59 n.172. Additionally, because state and local governments demanded similar assurances in the statutes implementing NAFTA and the Uruguay Round Agreements, in both instances the legislation creates a process of consultation for subnational governments. Id. at 59 .

${ }^{102}$ Banco Nacional de Cuba v. Sabbatino, 376 U.S. 398, 425 (1964). 
serve the important role of coordinating information regarding local initiatives. In exchange for permitting state and local governments the flexibility to experiment, national coordinating agencies (described below) should require state and local actors to share their knowledge regarding implementation and compliance, ${ }^{103}$ in order to encourage exchange of information, mutual learning, and coordination. In working with these state and local actors as true partners in devising broad national objectives (e.g., securing women's human rights), national coordinating agencies could then monitor compliance with these objectives through best practice performance standards developed at the local level and shared with other communities while, at the same time, strengthening democratic accountability through participation of people in decision making that affects them.'

While dialogic federalism anticipates that the federal government will play the role of coordination, where the government is unwilling or unable, other national entities could fill this gap. These entities might include national networks of state and local governments ${ }^{105}$ or

${ }^{103}$ One model for assessing compliance with a treaty from which other states and localities could learn is San Francisco's CEDAW gender analysis guidelines, which assist in monitoring the implementation of CEDAW, the main treaty guaranteeing women's rights, at the local level. See S.F. COMM'N ON THE STATUS OF WOMEN \& CEDAW TASK FORCE, A GENDER ANALYSIS: IMPLEMENTING THE CONVENTION ON THE ELIMINATION OF ALL FORMS OF DISCRIMINATION AGAINST WOMEN (1999) [hereinafter CEDAW TASK FORCE, A GENDER ANALYSIS], available at http://www.ci.sf.ca.us/cosw/cedaw/pdf/ cedaw.pdf. For further discussion see infra note 130, describing San Francisco's CEDAW gender analysis guidelines, and note 143, explaining that San Francisco's CEDAW ordinance has been identified by the United Nations Development Funds for Women in its collection of best practices worldwide for implementing CEDAW.

${ }^{104}$ Dorf \& Sabel, supra note 29, at 267. Dorf and Sabel are quick to distinguish the broad freedom they seek for subnational government actors from the abdication of federal responsibility thinly disguised as experimentalism in the context of welfare reform achieved through devolution. Id. at 434-38. Far from offering states increased freedom to experiment, the 1996 Welfare Reform Act imposed a number of federal goals concerning work requirements, as well as federal restrictions on eligibility (for example, by declaring legally resident aliens ineligible for Supplemental Security Income or food stamps). Id. at $435 \&$ n.541, 436. Clearly, this "new legislation flies in the face of the localism that ostensibly animates it." Id. at 437.

${ }^{105}$ Cf. Resnik, supra note 17 (manuscript at $57 \mathrm{n} .263$ ) (noting that the Supreme Court missed an opportunity to develop a more complex understanding of federalism when it failed to consider the role of national organizations of state elected officials in developing a nuclear waste disposal proposal that was adopted by Congress). In New York v. United States, 505 U.S. 144 (1992), the Court struck down the Congressional initiative adopting the proposal on the grounds that the requirements it placed on states violated anticommandeering principles. 
NGOs. ${ }^{106}$ Thus, a dialogic federalism account of constitutionalism differs from democratic experimentalism in at least one critical respect: it envisions a role for state and local participation even before there is a federal commitment to coordinate this participation.

When it plays the coordinating role, the federal government may be able to sidestep a central dilemma that has arisen in the context of enforcing international norms in a federalist system: while Congress cannot commandeer states under U.S. domestic law, international law essentially depends on a form of commandeering. ${ }^{107}$ On my reading, this dilemma results in part because the U.S. federal government is caught between a negative rights paradigm that stems from its domestic legal traditions and a mixed-rights approach that captures both negative and positive obligations, which spring from the fuller conception of rights found in international human rights law. Indeed, international law requires national governments to implement legislation and makes national governments liable for failure to bring constituent actors into compliance. ${ }^{108}$ By working cooperatively with state and local governments to achieve domestic implementation of human rights, the federal government need not commandeer the states. ${ }^{109}$

${ }^{1066}$ See Benvenisti, supra note 92, at 206 (proposing a theory of transnational institutions in which well-informed NGOs could step in to play coordinating roles where government does not).

${ }^{107}$ See Dorf \& Sabel, supra note 29, at 427 n.515 (" [I] nternational law . . . depends for its enforcement largely on national implementing legislation-what the Court would call commandeering.").

${ }^{108}$ See, e.g., ICCPR, supra note 5, at art. 2, para. 2, S. EXEC. DOC. E, 95-2, at 24, 999 U.N.T.S. at 173-74 ("[E] ach State Party to the present Covenant undertakes to take necessary steps . . . to adopt such legislative or other measures as may be necessary to give effect to the rights recognized in the present Covenant."). Note that the federal government can also be held accountable for violations of both subnational governments, see, e.g., ICCPR, supra note 5, at art. 50, S. EXEC. DOC. E, 95-2, at 38, 999 U.N.T.S. at 185 ("The provisions of the present Covenant shall extend to all parts of federal States without any limitations or exceptions."), and private actors, when the federal government is on notice and has the capacity to take corrective action, but fails to act. See Velasquez Rodriquez Case (Hond.), 4 Inter-Am. Ct. H.R. (ser. C.) No. 4, at para. 172 (1988) (explaining that a State may be internationally responsible for human rights violations that are not directly imputable to it because of a "lack of due diligence to prevent the violation or respond to it"), available at http://wwwl.umn.edu/ humanrts/iachr/b_11_12d.htm.

${ }^{1099}$ For a classic statement on the inefficiencies involved in commandeering states, see Roderick M. Hills, Jr., The Political Economy of Cooperative Federalism: Why State Autonomy Makes Sense and "Dual Sovereignty" Doesn't, 96 MICH. L. REV. 813, 893-900 (1998). See also Richard A. EPSTEIN, BARGAINING WITH THE STATE 145-57 (1993) (examining the problems that arise when the federal government imposes limits on the powers of the states to bargain with their citizens within the context of various government programs). 
Curiously, this cooperative federalism is reinforced by a sense of competition as well. As NGOs increasingly attempt to use the global marketplace as a means through which to exact economic retribution on governments (at whatever level) that fail to observe human rights, this economic discipline facilitates competition that stimulates "races to the top" toward improved compliance. ${ }^{110}$ This "co-opetition"111 approach to federalism maintains the national government as a primary site for international lawmaking and accountability, while encouraging cooperation with subnational authorities, who in turn may be incentivized to adopt human rights standards through competitive pressures that "ratchet" standards upward. ${ }^{112}$

\section{A DIALOGIC FEDERALIST TYPOLOGY}

From a dialogic federalist perspective, intergovernmental dialogue proceeds along at least three different tracks, depending on the linkage between national and subnational governments. The first track involves state and local adoption of international human rights standards where the federal government has failed to ratify a treaty. As has been the case with CEDAW, state and local enactments adopting treaty standards call for federal ratification, and in this sense invite dialogue with the federal government. ${ }^{113}$ A second track involves state

${ }^{111}$ Cf. Spiro, supra note 17, at 568-69, 588-89. Note that Professor Spiro goes a step further than I am prepared to go in this Article in that he suggests that it would be "more efficient" to hold state and local governments liable for violations along with the federal government under a "condominium responsibility" concept-an approach that would operate along the lines of joint and several liability under tort law. Id. In addition to suggesting applying the stick, Professor Spiro also suggests using the carrot approach by enabling state governments to be treaty partners. Id. at 590-95. As a possible precedent, he explores the opt-in model of treaty accession used in the trade context. Id. at 592-93. Specifically, Spiro discusses the Agreement on Government Procurement, which applies to "sub-central" governments only to the extent that such entities agree to coverage, as is indicated by notification to the World Trade Organization by the relevant central government (with the latter, remaining the only formal parties to the agreement). Id. "The regime gives sub-national authorities, in effect, an option to accept the treaty regime." Id. at 592; see also Paul Blustein, Thinking Globally, Punishing Locally, WASH. POST, May 16, 1997, at G1 (explaining that economic sanctions imposed by state and local governments against objectionable foreign regimes "raise the specter of multi-national companies being forced to make costly choices between giving up lucrative contracts with government agencies or foregoing business in some of the world's most promising markets").

111 Cf. AdAM M. BRANDENBURGER \& BARRY J. NALEBUfF, CO-OPETITION 11-39 (describing ways in which cooperation and competition can be mutually reinforcing in the business context).

${ }^{112}$ Fung et al., supra note 100, at 2.

${ }^{113}$ Similarly, cities that have urged their states and the federal government to sup- 
and local efforts to implement international obligations that the federal government has adopted through ratification or other acknowledgement that it is bound (for example, through the application of customary international law) but not fully implemented. As has been the case with the consular notification requirement for foreign nationals arrested and detained-an obligation under the Vienna Convention on Consular Relations-state and local legislative adoption of such requirements invites dialogue with federal efforts to implement the requirement more fully, and in so doing may allay federalism concerns the United States has expressed in the context of international criticism where the obligation has not been observed. ${ }^{114}$ A third track-involving state and local efforts to apply human rights principles contained in treaty provisions for which the United States has entered a reservation-is possible, but to my knowledge is still hypothetical. In the context of juvenile death penalty litigation, for example, defense lawyers have argued that the U.S. treaty reservation concerning the prohibition on the juvenile death penalty in the International Covenant on Civil and Political Rights ${ }^{115}$ is invalid; however, state and

port the U.N. Commission on Human Rights' call for a death penalty moratorium may be read as initiating dialogue with these states and the federal government.

${ }^{114}$ For an expression of the U.S. federalism concerns in this context, see LaGrand Case (F.R.G. v. U.S.), 2001 I.C.J. No. 104 (June 27), available at http://www.icj-cji.org, a case challenging the death sentences imposed on two German nationals by the state of Arizona. In that case, the United States contended that one "constraining factor" on its ability to satisfy the international obligation regarding consular notification was "the character of the United States of America as a federal Republic of divided powers." Id. at para. 95. While the United States has adopted the Vienna Convention on Consular Relations, it has frequently failed to ensure the enforcement of the rights of foreign nationals under the treaty. See Rebecca E. Woodman, International Miranda? Article 36 of the Vienna Convention on Consular Relations, J. KAN. B. Ass'N, June/July 2001, at 41-42 (suggesting that failure to enforce the rights of foreign nationals under the Convention "not only violates international law, it weakens the status and authority of the United States in the international community"). Some states and local governments such as Florida have incorporated the consular notification obligation directly into state law. FLA. STAT. ANN. $\$ \S 901.26(3), 288.816(2)$ (f) (West 2001). These subnational efforts invite dialogue with federal efforts to provide for more effective implementation of the treaty. See, e.g., Catherine Brown, Consular Notification Liaison and Legal Advisor, State Department, International Law \& the Work of Federal \& State Governments, Remarks at the American Society of International Law 2001 Annual Meeting (Apr. 4-6, 2001) ("[W] hat I have been trying to do is get federal, state and local law enforcement judicial and other officials to comply with these notification requirements.").

${ }^{115}$ See U.S. RUDs to the ICCPR, supra note 5, at 8070 (" $[\mathrm{T}]$ he United States reserves the right ... to impose capital punishment on any person ... duly convicted under existing or future laws permitting the imposition of capital punishment, including such punishment for crimes committed by persons below eighteen years of age."). 
local governments have not yet undertaken legislative initiatives to advance this prohibition or to repeal laws that are inconsistent with it.

Only the first track along which dialogic federalism operates is explored in further detail here. It is currently the most active approach and, therefore, provides the richest source for examination. State and local adoption of international human rights standards, where the federal government has failed to ratify a treaty, represents a response to the federal government's failure to incorporate the standards. One could view with despair the federal government's failure to ratify several human rights treaties, ${ }^{116}$ seeing this as an indication that the national government is unwilling or unable to implement these norms through the normal channels provided under the U.S. Constitution and anticipated by international law. ${ }^{117}$ This failure is rooted in the structure of international law, which derives primarily from the will and consent of national governments. ${ }^{118}$ However, rather than view these conditions with despair, one could also see this failure as the result of decisions made by federal officials who were democratically elected and who, in this sense, represent our democracy at work. A dialogic approach views these institutional realities "as creating the occasion for, indeed in part anticipating, a radical redefinition of our democratic and constitutional ideals." ${ }^{119}$ Therefore,

${ }^{116}$ See supra note 55 for examples of treaties the United States has signed but not ratified.

${ }^{117}$ Paradoxically, the initiative taken by state and local governments in supporting human rights where the federal government is unwilling or unable to do so mirrors developments in the international criminal justice area where, under the notion of complementarity, international institutions step in to enforce human rights norms where national governments are unwilling or unable. See, e.g., Rome Statute of the International Criminal Court, June 17, 1998, 37 I.L.M. 999, 1003 (establishing an international court that is complementary to national criminal jurisdictions). Of course, in the United States, the federal government historically also has played this backstopping role, particularly with respect to civil rights, where, until quite recently (and to some extent today), the assertion of "states' rights" and "local control" indicated a lack of willingness or ability by state and local governments to enforce civil rights. See, e.g., RiCHARD KLUGER, SIMPLE JUSTICE: THE History OF BROWN V. BOARI) OF EDU(CATION AND BLACK AMERICA's STRUGGLE FOR EQUALITY 748-78 (1976) (framing Brown v. Board of Education, 347 U.S. 483 (1954), and civil rights legislation in general, as efforts by the federal government to control local enforcement of civil rights).

${ }^{118}$ See Christine Chinkin, Normative Development in the International Legal System, in COMMITMENT AND COMPLiance: THE ROLE OF NON-BINDING NORMS IN THE INTERNATIONAL LEGAL SYSTEM 21, 41 (Dinah Shelton ed., 2000) ("[T] he reality is that [S] tates and other international actors have recourse to diverse methods of setting agendas, influencing behavior, and supplementing and shading international obligations.").

${ }^{119}$ Gerstenberg \& Sabel, supra note 59, at 5. 
this Article takes an optimistic view of these conditions, seeing in them an opportunity to reconceptualize available avenues for deliberation and develop new methods that broaden and deepen consensus over human rights law.

The "adoption" of human rights treaties and standards at the state and local levels largely represents a form of communication through which people and communities, who are more effectively able to mobilize at the local level, signify the need for the federal government to play a more active role in human rights lawmaking. ${ }^{120}$ In fact, many of the ordinances and resolutions adopted by state and local governments explicitly call for the federal government to adopt particular human rights treaties and standards. ${ }^{121}$ In this sense, the direct incorporation of human rights norms by state and local governments should be seen as providing a method for creating momentum and building pressure for change at the federal level.

Following the approach taken in scholarship on democratic experimentalism, I am going to theorize by looking at the facts, that is, by looking at what is actually happening on the ground in two areas of state and local activity where a federal role is absent: women's human rights and capital punishment.

1. State and Local CEDAW Activity: Despite the representations made by the Clinton administration to "bring Beijing home," the U.S. government has done very little at the federal level to incorporate the commitments undertaken by governments at the United Nations Fourth World Conference on Women, held in Beijing, China, in $1995 .{ }^{122}$ An Inter-Agency Council on Women was established to coordinate the incorporation of aspects of the Beijing Platform for Action. ${ }^{123}$ However, the work of the Inter-Agency Council has been largely symbolic. ${ }^{124}$ Additionally, the United States has yet to ratify

$\stackrel{\mathrm{ran}}{\rightarrow} C f$. Elizabeth S. Anderson \& Richard H. Pildes, Expressive Theories of Law: A General Restatement, 148 U. PA. L. REV. 1503, 1520-27 (2000) (viewing the democratic state as a collective agent and analyzing the expressive dimensions of state action).

${ }_{122}^{12}$ See infra notes 131-133, 138-141, 159 and accompanying text.

${ }^{122}$ See Benjamin D. Knaupp, Comment, Classifying International Agreements Under U.S. Law: The Beijing Platform as a Case Study, 1998 BYU L. REv. 239, 262 ("The United States has signed the [Beijing] Platform, but has proclaimed that it is not binding .... Without a clear understanding of the legal status of the Beijing Platform and other U.N. declarations, confusion and tension between Congress and the President in the sphere of foreign affairs powers will worsen.").

${ }^{123}$ Rhonda Copelon, The Indivisible Framework of International Human Rights: A Source of Social Justice in the U.S., 3 N.Y. CITY L. REV. 59, 77 (1998).

${ }^{124}$ Id. at 77 ("While [the Inter-Agency Council] gives women a limited route to influence government policy... the potential of the Beijing Platform is not felt be- 
CEDAW, the main treaty guaranteeing women's rights. Furthermore, while the executive branch pointed to the Violence Against Women Act (VAWA) as evidence of its compliance with the ICCPR in its report to the U.N. Human Rights Committee, ${ }^{125}$ part of VAWA was recently struck down by the U.S. Supreme Court. ${ }^{126}$ In United States $v$. Morrison, the Supreme Court held that Congress lacked authority to enact the civil remedy that provides a cause of action for VAWA. ${ }^{127}$ In so doing, the Court completely ignored the fact that international human rights law (as incorporated into U.S. law) not only authorizes Congress to enact effective remedies to challenge gender-based violence, but in fact compels the U.S. government to provide such remedies to meet current obligations under the treaty."

While federal implementation of international standards concerning women's rights has lagged, some local governments have incorporated CEDAW directly into local law. The City of San Francisco pioneered this approach by making CEDAW part of its local law in 1998, three years after the Beijing Conference. ${ }^{129}$ With respect to the requirements imposed by CEDAW at the international level, the city's Juvenile Probation Department and its Department of Public Works have filed reports containing gender analyses of their delivery of serv-

cause many U.S. women are unaware of its provisions ... [or] do not use it as a platform for action or an instrument of accountability.").

${ }^{125}$ See Press Release, United Nations General Assembly, Human Rights Committee Begins Considering Initial Report of United States 8, U.N. Doc. HR/CT/400 (Mar. 29, 1995) (reporting statement of Jo Ann Harris, assistant attorney general in the United States Department of Justice Criminal Division, that VAWA "was the most comprehensive federal effort to date to address violence against women").

${ }^{126}$ See United States v. Morrison, 529 U.S. 598, 627 (2000) (concluding that Congress lacked the constitutional authority to enact VAWA's civil remedy for victims of gender-motivated violence under both the Commerce and Equal Protection Clauses ).

${ }^{127}$ Id.

${ }^{128}$ See, e.g., ICCPR, supra note 5, at art. 2, para. 3, S. EXEC. Doc. E, 95-2, at 24, 999 U.N.T.S. at 174 (requiring that each State party to the Covenant take necessary steps to give effect to the rights recognized in the Covenant and to ensure effective remedies should such rights be violated); Brief of Amici Curiae on Behalf of International Law Scholars and Human Rights Experts in Support of Petitioners at 2, United States v. Morrison, 529 U.S. 598 (2000) (No. 99-0029) ("The text of the treaty, in conjunction with subsequent unanimous and binding interpretations by the international community, make clear that the ICCPR requires the U.S. to provide protection from genderbased violence from both private persons and public officials."); see also supra notes 5657 and accompanying text (discussing the United States' failure to enact the legislation required to fulfill its international treaty obligations).

129) SAN Francisco, Cal., Administrative CODE, ch. 12K (2001), available at http://www.amlegal.com/sanfranadmin/lpext.dll?f=templates\&fn=main-j.htm\&2.0. 
ices, employment practices, and budget allocation. ${ }^{130}$ In signing the city ordinance, Mayor Willie Brown, Jr., pointed out: “[ $t]$ he United States is the only industrialized country in the world that has yet to ratify CEDAW." ${ }^{131}$ Sending a signal to Washington, Mayor Brown stated: "We want to set an example for the rest of the nation because it is long overdue." ${ }^{\text {"132 }}$ Similarly, explaining why her organization and other advocacy groups mobilized in support of the city ordinance, Krishanti Dharmaraj, the Executive Director of the Women's Institute for Leadership Development (WILD) for Human Rights said: "We couldn't just keep waiting for the federal government."133 While it may be too soon to evaluate the impact of the ordinance, its value may be more than symbolic. The city ordinance may have a concrete impact on the allocation of services (such as extra street lighting in high crime areas to assist in preventing violence against women, ${ }^{134}$ and summer sports programs for girls), employment (in city agencies ${ }^{135}$ and in the private sector $\left.{ }^{136}\right)$, and differential arrest patterns.

130) See CEDAW TASK FORCE, A GENDER ANALYSIS, supra note 103, at 14-64 (documenting the efforts made by these city departments to conform with CEDAW requirements).

${ }^{131}$ Gretchen Sidhu, San Francisco Plunges Ahead in Adopting a CEDAW Treaty of Its Own, CHI. TRIB., Aug. 2, 1998, § 13, at 8.

${ }_{132}$ Id. San Francisco has long been a leader in human rights, having hosted, for example, the U.N. Conference on International Organizations, during which the U.N. Charter was adopted. See The UN Charter as History (Jane D. Weaver rep.), 89 AM. SOC'Y INT'L L. PROC. 45, 59 (1995) (“[T]he status of the individual in human rights first received recognition in the San Francisco UN Conference.”).

${ }^{133}$ Sidhu, supra note 131.

${ }^{134}$ See id. ("[E]xtra street lights [are] something women have demanded for years and male city planners have routinely ignored.").

${ }^{135}$ SAN Francisco, CAL., Administrative Code, ch. 12K.3(a)(1) (2001) ("The City shall take all appropriate measures to eliminate discrimination against women and girls in the City of San Francisco in employment and other economic opportunities . . . . .), available at http://www.amlegal.com/sanfranadmin/ lpext.dll?f=templates\&fn=main-j.htm\&2.0. The City of San Francisco is the largest employer in the Bay Area. Sidhu, supra note 131.

${ }^{1366}$ SAN Francisco, CAL., Administrative CODE, ch. 12K.3 (2001) ("The City shall ensure that the City does not discriminate against women in areas including employment practices, allocation of funding and delivery of direct and indirect services."), available at http://www.amlegal.com/sanfranadmin/lpext.dll? $\mathrm{f}=$ templates\& $\mathrm{fn}=$ mainj.htm\&2.0; see also Sidhu, supra note 131 (suggesting that the City may be able to require that women be appropriately represented in management of private firms bidding for city contracts and licenses).

${ }_{137}$ Women arrested in San Francisco say they are treated differently from men. For example, Sonia Melara, executive director of San Francisco's Commission on the Status of Women, explains that women dancers in legal exotic clubs have been arrested as prostitutes, while the male club owners go free. Sidhu, supra note 131. 
The symbolic value of the San Francisco ordinance, however, cannot be underestimated. Following San Francisco's lead, the Los Angeles City Council has adopted a Resolution in Support of CEDAW. ${ }^{138}$ Moreover, as of August, 2000, 39 cities, 17 counties, 16 states, and the Territory of Guam had adopted resolutions calling for the United States to ratify CEDAW. ${ }^{139}$ Unlike San Francisco's CEDAW law, the resolutions of the other cities and states are nonbinding. In most cases, the resolutions can be read as seeking local implementation as well as national ratification. ${ }^{140}$ In this sense, much of the local CEDAW work is directed toward the goal of building momentum to pressure the U.S. government to ratify CEDAW, rather than enlisting cities and states to function as laboratories for a range of experimentation. ${ }^{141}$ Nonetheless, the coordination of these local efforts to affect national norms operates along democratic experimentalist lines in that local governments are learning from each other through national organizations of state and local elected officials, as well as through networks of scholars and activists.

Besides the value of building political momentum, this local treaty work also helps to translate broad abstract principles contained in human rights treaties into concrete, definable standards on the ground. Assuming the federal government eventually adopts CEDAW, the precedent developed at the local level will help inform implementation at the national and even international level. This local work on the periphery, then, may help redefine core activities, and in so doing may ultimately help undermine the dichotomy between core and periphery. ${ }^{142}$

${ }^{138}$ Los Angeles City Resolution in Support of CEDAW, L.A. City Council (L.A., Cal., 2000), http://www.ci.la.ca.us/csw/html/cswpge3d.htm.

${ }^{139}$ WILD for Human Rights: CEDAW Around the U.S., at http://www.wildforhumanrights.org/cedaw_around_us.html (last visited Nov. 26, 2001). Other cities, such as Seattle, are considering adopting similar resolutions. See Seattle Women's Commission: Legislative Action, at http://www.cityofseattle.net/ civilrights/swc/legislat.htm (last visited Nov. 26, 2001) (listing "Support any CEDAW legislation" as one of six legislative priorities for the 2001 state legislative session).

${ }^{140}$ Cf. Resnik, supra note 17 (manuscript at 52) (“[CEDAW p] roponent's goals are to change both local and national laws; their means deploy local actors working in concert with outsiders.").

${ }^{141}$ Id. (manuscript at 52-53) ("To conceive of local action as ... indigenous to a particular place is to miss how much of that work is a product of broad efforts to shift social policy.").

${ }^{42}$ Cf. Dorf \& Sabel, supra note 29, at 445 ("[A]s democracy increasingly comes to mean decentralized, direct deliberation, it will be increasingly difficult to distinguish the citizen's participatory rights in these particular settings from those more general 'process-perfecting' rights to democratic participation that are frequently taken as the 
But, rather than take a passive role, the federal government should play a more active role in these local efforts. For example, the federal government could use the Inter-Agency Council on Women as a national coordinating agency, pooling information, monitoring best practices, ${ }^{143}$ and feeding these participatory experiences from local communities into the effort to build national support for federal treaty action.

2. State and Local Calls for a Death Penalty Moratorium: State and local calls for a death penalty moratorium often rely on international standards. In recent years, the United States has come under intense international criticism for its death penalty practices. ${ }^{14}$ However, many states continue to execute minors and allow tremendous race disparities in the application of the death penalty, ${ }^{145}$ in violation of international law. ${ }^{146}$ While the death penalty itself is permitted under

most fundamental of all political liberties.").

${ }^{143}$ The San Francisco ordinance has already been identified by the United Nations Development Fund for Women in its collection of best practices worldwide for implementing CEDAW. UNITED NATIONS DEVELOPMENT FUND FOR WOMEN, BRINGING EQUALITY HOME: IMPLEMENTING THE CONVENTION ON THE ELIMINATION OF ALL FORMS OF DISCRIMINATION AGAINST WOMEN, available at http://www.unifem.undp.org/cedaw/cedawen7.htm (last visited Oct. 25, 2001).

${ }^{144}$ See, e.g., Roger Cohen, America the Roughneck (Through Europe's Eyes), N.Y. TIMES, May 7, 2001, at A10 (quoting the British paper, The Guardian, which called American's position on the death penalty "morally untenable," and explaining that America's "ease" with the death penalty is contributing to "the growing hostility to the United States"); Editorial, Europe's View of the Death Penalty, N.Y. TIMES, May 13, 2001, § 4 (Week in Review), at 12 ("European politicians and intellectuals, who view the death penalty as a human rights issue, are incredulous that Americans support a punishment that fails to deter crime, targets mainly those who cannot afford a decent lawyer, is used on the mentally retarded and has often gotten the wrong man.”).

${ }^{14.5}$ See, e.g., AMNESTY InTERnATIONAL, KIlling With PREJUDiCE: RACE AND THE DEATH PENALTY IN THE USA, at http://www.amnestyusa.org/rightsforall/dp/race/ index.html (last visited Oct. 25, 2001) [hereinafter KILLING WITH PREJUDICE] (showing "how the death penalty in the U.S. is applied disproportionately on the basis of race, ethnicity and social status").

${ }^{146}$ For the prohibition on the juvenile death penalty adopted by the United Nations see ICCPR, supra note 5, at art. 6, para. 5, S. EXEC. DOC. E, 95-2, at 25, 999 U.N.T.S. at 175; and Convention on the Rights of the Child, supra note 55, at 55, stating that "capital punishment ... shall [not] be imposed for offenses committed by persons below eighteen years of age," which is not ratified by the United States. For the prohibition on race discrimination adopted by the United Nations, see ICCPR, supra note 5, at arts. 2, 26, S. EXEC. DOC. E, 95-2, at 24, 31, 999 U.N.T.S. at 173, 179, codifying member nations' obligation to protect the rights of all citizens equally. See generally International Convention on the Elimination of All Forms of Racial Discrimination, $\mathbf{S}$. EXEC. DOC. C, 95-2, at 1 (1965) (condemning racial discrimination and undertaking "to pursue by all appropriate means and without delay a policy of eliminating racial discrimination in all its forms and promoting understanding among all races"). 
international law as an exception to the right to life, ${ }^{147}$ the Second Optional Protocol to the ICCPR calls for its abolition, ${ }^{148}$ and the United Nations Commission on Human Rights has called for a moratorium on executions. ${ }^{149}$

In justifying U.S. death penalty practices to the Human Rights Committee-the treaty body that oversees the ICCPR-during the United States' first compliance hearing, State Department Legal Advisor Conrad Harper testified that the decision to retain the death penalty represented a democratic choice. ${ }^{150}$ Having entered a reservation to the ICCPR provision barring juvenile executions, the United States is one of only six nations that continues to execute minors. The United States stands in the company of Iran, Nigeria, and Saudi Arabia as the only countries that execute people for crimes they committed as juveniles. ${ }^{151}$

On the domestic front, there is a growing sense that the error rates $^{152}$ and race disparities ${ }^{153}$ in the application of the death penalty require its reevaluation. However, from a domestic political perspective, federal attempts to restrict or regulate the states' use of the death penalty would run afoul of federalism concerns-a point frequently raised by U.S. representatives in international fora in which U.S. death

${ }^{147}$ ICCPR, supra note 5, art. 6, para. 2, S. EXEC. Doc. E, 95-2, at 25, 999 U.N.T.S. at $174-75$.

${ }^{148}$ Second Optional Protocol, supra note 5.

${ }^{149}$ Resolution Supporting Worldwide Moratorium on Executions, Hum. Rts. Comm. (Apr. 1999), available at http://www.deathpenaltyinfo.org/UNStatements.html\#resolution (last visited Oct. 25, 2001).

${ }^{150)}$ U.N. GAOR, Hum. Rts. Comm., 53rd Sess., 1405th mtg. I 12, U.N. Doc. CCPR/C/SR.1405 (1995) (summarizing testimony by American representatives that "the decision to retain [the death penalty] reflected a serious and considered democratic choice of the American public" and that "it was not appropriate in that democratic system to dismiss considered public opinion and impose by fiat a different view").

America's Shame-Killing Kids, National Coalition to Abolish the Death Penalty, at http://www.ncadp.org/html/factl.html (last visited Oct. 25, 2001). By comparison, Pakistan and Yemen have just recently changed their laws to exclude the execution of offenders under the age of eighteen. People's Union for Civil Liberties, Amnesty International: Children and the Death Penalty; Executions Worldwide Since 1990, Apr. 2001, at http://www.pucl.org/reports/International/2001/executions.htm.

${ }_{152}$ See, e.g., James S. Liebman et al., A Broken System: Error Rates in Capital Cases, 1973-1995, at http://www.law.columbia.edu/instructionalservices/liebman (last visited Oct. 25, 2001) (presenting statistical evidence to show that America's death penalty system is persistently and systematically fraught with error).

${ }_{153}$ See, e.g., KILLING WITH PREJUDICE, supra note 145 (“[R]acial discrimination pervades the U.S. death penalty at every stage of the process ...."). 
penalty practices are criticized. ${ }^{154}$ Under international law, however, national governments can be held accountable for treaty violations of subnational governments and their officials. ${ }^{155}$ As described above, a way to sidestep this paradox of federalism is to incentivize state and local governments themselves to adopt human rights standards.

State and local initiatives calling for a moratorium cite international standards as authority, in the sense that international norms provide an interpretative device, not binding legal standards. For example, in a resolution calling on state officials in Maryland as well as federal officials to place a moratorium on executions, the Baltimore City Council cites an Amnesty International source that indicates that $80 \%$ of all executions in 1999 occurred in 4 countries-the United States, China, Iran, and the Democratic Republic of the Congo. ${ }^{156}$ Philadelphia has also passed a resolution calling for the Commonwealth of Pennsylvania to impose a moratorium on executions. ${ }^{157}$ Pointing out that "every nation in Europe and the vast majority of the democratic nations of the world have abolished the death penalty," the Philadelphia resolution also relies on the U.N. Human Rights Commission's call for an international moratorium on the death penalty. ${ }^{158}$ The Village of Yellow Springs, Ohio and the City Council of

${ }^{154}$ See, e.g., U.N. GAOR, Hum. Rts. Comm., 53d Sess., 1405th mtg. II 13, U.N. Doc. CCPR/C/SR.1405 (1995) (reporting that a large majority of American states permitted juveniles to be tried as adults in grave cases involving capital offenses at the age of either sixteen or seventeen).

${ }^{155}$ See, e.g., Bermann, supra note 101, at 60 (" $[\mathrm{T}]$ he treaty violations for which a nation is responsible include those committed not only by their own officials but also by sub-national governments and their officials."); see also IVAN BERNIER, INTERNATIONAL LEGAL ASPECTS OF FEDERALISM 83 (1973) ("On the authority of certain decisions, federal states are considered by most international law writers as responsible for the acts or omissions of their component units."); IAN BROWNLIE, PRINCIPLES OF PUBliC INTERNATIONAL LAW 449 (4th ed. 1990) ("A state cannot plead the principles of municipal law, including its constitution, in answer to an international claim."); Spiro, supra note 17, at 580 n.47 (citing RESTATEMENT (THIRD) OF FOREIGN RELATIONS LAW OF THE UNITED STATES, § 207(b) \& reporter's note 3 (1987)); Report of the International Law Commission on State Responsibility, [1971] 2 Y.B. Int'l L. Comm'n 193, 257, U.N. Doc. A/CN.4/217/ADD2). But see John Norton Moore, Federalism and Foreign Relations, 1965 DukE L.J. 248, 249 (1965) (discussing the area of "uncertainty regarding the relationship between state policies and the national foreign relations power").

${ }_{156}$ A Council Resolution Concerning: In support of a Moratorium on the Death Penalty (House Bill 388), Balt. City Council, Council Bill 00-0032 (Balt., Md. 2000).

${ }^{157}$ Resolution: Calling for a Moratorium on the Imposition of Any Death Penalty in the Commonwealth of Pennsylvania Until a Fair and Impartial Study of the Application of the Death Penalty Is Conducted, Phila. City Council (Phila., Pa., 2000).

${ }^{158}$ Id. 
Santa Cruz, California, have also relied on the U.N. Human Rights Commission's call for a death penalty moratorium in passing resolutions requesting that their respective states and the federal government impose a moratorium on the death penalty. ${ }^{159}$

The federal government has a role to play in coordinating state and local initiatives that call for the observance of human rights standards in the death penalty context. One possibility is for the federal government to play a coordinating role through the Inter-Agency Working Group on Implementation of Human Rights Treaties established under Executive Order 13,107 to oversee implementation of the Race and Torture Conventions. ${ }^{160}$ In particular, the Inter-Agency Working Group could review best practices and pool information so that these participatory experiences could filter up from local communities to build support for national standards. Such support is necessary, for example, to create momentum for a review of the U.S. reservation on the ICCPR provision barring juvenile executions. According to Executive Order 13,107, the executive branch is required to review the appropriateness of all existing reservations to human rights treaties.

\section{THE ROLE OF INTERGOVERNMENTAL DIALOGUE IN SHAPING NATIONAL LAW}

The dialogic approach to incorporating human rights law explored here engages the debate over federalism and international lawmaking by advancing a path between the two approaches on either side of this debate. The traditional (and predominant) approach held by international law scholars is that, as a constitutional and practical matter, the federal government is the primary site for implementation and enforcement of international law. This traditional view takes many forms. In response to revisionist critics who claim federal courts are restricted from interpreting customary international law on federalism grounds, ${ }^{162}$ scholars who follow the traditional approach have

159 Call for a Moratorium of Executions, Council of the Vill. of Yellow Springs, Res. 99-39 (Vill. of Yellow Springs, Ohio 1999); A Resolution of the City Council of the City of Santa Cruz Requesting That the State and Federal Governments Enact and Adopt Legislation Imposing a Moratorium on Executions at Least Until Fair and Equitable Policies and Practices Are Implemented, City Council of the City of Santa Cruz, Res. NS-23, 806 (Santa Cruz, Cal., 1998).

Exec. Order No. 13,107, 63 Fed. Reg. 68,991-68,992 (Dec. 15, 1998).

${ }^{161} I d$. at 68,991 .

${ }^{162}$ See supra note 39 and accompanying text. 
defended the authority of federal courts in interpreting customary international law. ${ }^{163}$ These scholars draw support from the vision of the nation's Founders, who, due to the failure of the Articles of Confederation, framed a Constitution establishing a national government "to articulate uniform positions on such uniquely federal matters as foreign affairs and international law." ${ }^{164}$ Additionally, these scholars point to the Constitution's assignment of international lawmaking powers to the federal government and divestment of such powers from state and local governments. ${ }^{165}$ Moreover, these scholars note that state and local governments are unrecognized as actors within the structure of international law. ${ }^{166}$ Finally, these scholars argue that Supreme Court precedent acknowledges constitutional and policy considerations underlying the need for the nation to speak with "one voice" in foreign affairs through the president. ${ }^{167}$ In response to revisionist critics who claim federal courts are restricted from interpreting customary international law on separation of powers grounds, scholars who subscribe to the traditional view defend the jurisdiction of federal courts over international claims, even in the absence of action from the political branches enacting customary international law. ${ }^{168}$ To some extent, traditionalists also support the self-executing nature of international law in the absence of implementing legislation from

${ }^{163}$ See, e.g., Koh, supra note 10 , at 1827 (defending the traditional ability of federal courts to incorporate norms of CIL into federal law as "a sensible, settled rule that all three federal branches and the fifty states have consistently followed"); Neuman, supra note 10 , at 376 (arguing that federal courts should continue to "apply only those norms [of CIL] that external evidence demonstrates embody genuine international legal obligations binding on the United States"); Stephens, supra note 10, at 397 (" $[\mathrm{T}]$ he determination of the content of customary international law and of whether or not it applies in a given situation is a federal question, which triggers federal court jurisdiction and on which federal courts decisions are binding on the states.").

${ }^{164}$ Koh, supra note 10 , at 1825 ; see also supra note 42 and accompanying text (presenting historical arguments that the framers intended that the federal government control U.S. foreign relations).

${ }^{165}$ See supra note 43 and accompanying text (analyzing the text of the Constitution to argue that the federal government retains a virtual monopoly over U.S. involvement in foreign affairs).

${ }^{166}$ See, e.g., Jessup, supra note 15, at 743 ("The several states of the Union are entities unknown to international law.").

${ }^{167}$ Crosby v. Nat'l Foreign Trade Council, 530 U.S. 363, 381 (2000); see also cases and sources cited supra notes 14-15, 45 (analyzing Supreme Court cases and other legal scholarship indicating that uniform foreign policy requires federal court jurisdiction).

${ }^{168}$ See, e.g., Koh, supra note 10, at 1842 ("[W] hen customary international norms are well-defined, the executive branch has regularly urged the federal courts to determine such rules as matters of federal law."). 
Congress, ${ }^{169}$ under the theory that political branches have already had input in the making of customary international law (through state practice) and of treaties (through the ratification process, in which the President "makes" treaties with the advice and consent of the Senate). Furthermore, these scholars criticize the practice through which political branches attempt to limit the role of the federal courts in considering treaty matters by attaching non-self-executing declarations to treaties. These scholars question whether such non-selfexecuting declarations have either domestic or international effect, ${ }^{170}$ and criticize these declarations as violating the spirit of the Supremacy Clause's declaration that treaties are the law of the land. ${ }^{171}$ Relying on Supreme Court precedent, these scholars also argue that the treaty power authorizes Congress to legislate in areas beyond those specifically conferred on Congress and is not subject to Tenth Amendment limitations (at least of the non-commandeering variety). ${ }^{172}$

Revisionist scholars challenge the traditional view by claiming that the federal government's role in making international law is limited by federalism and separation of powers principles. The revisionist view finds different forms of expression that correspond to and challenge the various aspects of the traditional approach outlined above. Perhaps the most prominent attack by revisionists has been on the role of the federal courts in determining customary international law. ${ }^{173}$ On both federalism and separation of powers grounds, revi-

${ }^{169}$ See, e.g., Flaherty, supra note 56, at 2151-52 (focusing on eighteenth-century British and American history to argue that the traditional understanding of treaties as self-executing is correct); Vazquez, supra note 56, at 718 (arguing that Congressional action is needed only in situations where legislative authority is required to do "what the treaty makers agreed to do but lack the [constitutional] power to accomplish").

${ }^{170}$ See, e.g., Damrosch, supra note 56, at 515 (observing a pattern in which the Senate tries to weaken the domestic legal effect of treaties by attaching non-self-executing declarations and arguing for the limited use of these declarations); Henkin, supra note 64, at 346 ("The Framers intended that a treaty should become law ipso facto, when the treaty is made; it should not require legislative implementation to convert it into United States law.").

${ }^{171}$ See HENkIN, supra note 56, at 201-02 (calling the recent practice of declaring some apparently self-executing treaties non-self-executing "anti-Constitutional").

${ }^{172}$ See, e.g., Golove, supra note 8, at 1281-83 (defending the viability of Missouri v. Holland, 252 U.S. 416 (1920), and arguing that the Tenth Amendment does not act as an affirmative restraint on Congress' delegated treaty power).

${ }^{173}$ The two scholars most closely identified with this position are Curtis Bradley and Jack Goldsmith. See Bradley \& Goldsmith, Critique of the Modern Position, supra note 11 , at 856 (rejecting the traditional inclusion of international law within federal common law due to a lack of "domestic federal authorization for federal courts to interpret and apply [CIL] as federal law"); Bradley \& Goldsmith, Current Illegitimacy, supra note 11, at 349 (defending their earlier position that "federal courts should not 
sionist scholars contend that federal courts lack jurisdiction over customary international law in the aftermath of the Supreme Court's famous statement in Erie that "there is no federal general common law." ${ }^{174}$ Because customary international law is a form of common law, revisionists claim that determinations of customary international law are questions of state law that "federal courts should not apply ... as federal law without some authorization to do so by the federal political branches." ${ }^{175}$ The federalism critique also extends to the treaty context in the sense that revisionists claim Congressional treaty power is subject to the Tenth Amendment and cannot extend to areas beyond Congress' enumerated powers. ${ }^{176}$ Additionally, revisionists question traditionalist concerns over the practice of declaring treaties nonself-executing by insisting that this practice safeguards the separation of powers. ${ }^{17}$

The main fault lines between the traditional and revisionist approaches-federalism and separation of powers-essentially center on questions of authority. Consider how each dimension of the debate frames a question reflecting anxiety over who has authority to bind and what laws bind. Do federal courts have independent authority to make determinations regarding customary international law (absent action by the political branches), or does this authority reside solely in state courts, as courts of general jurisdiction? ${ }^{178}$ Does Congress have

apply [CIL] as federal law without some authorization to do so by the federal political branches"). For earlier work on the same point, see Phillip R. Trimble, A Revisionist View of Customary International Law, 33 UCLA L. REV. 665, 672, 707-16 (1986), in which he states, "courts should never apply customary international law except pursuant to political branch direction"; and A.M. Weisburd, State Courts, Federal Courts, and International Cases, 20 YALE J. INT'L L. 1, 48 (1995), stating “[CIL] is not federal law and thus provides no authority for imposing limits [on the federal government]."

${ }^{174}$ Erie R.R. Co. v. Tompkins, 304 U.S. 64, 78 (1938); see Bradley \& Goldsmith, Current Illegitimacy, supra note 11, at 324 (arguing that to be consistent with Erie, a "new federal common law must be authorized in some fashion by the U.S. Constitution of a federal statute").

${ }^{175}$ Bradley \& Goldsmith, Current Illegitimacy, supra note 11, at 349.

${ }^{176}$ See Bradley, Treaty Power, supra note 11, at 435 ("[W]hatever limitations the Tenth Amendment does impose, it is not evident ... why these limitations should not apply to the treaty power.").

${ }^{77}$ See, e.g., Yoo, Globalism and the Constitution, supra note 56, at 2074-80 (using historical and comparative evidence to respond to traditionalist critiques of non-selfexecution as being at odds with the Supremacy Clause and inconsistent with the Framers' notions); Yoo, Treaties and Public Lawmaking, supra note 56, at 2220 ("Treaties cannot receive judicial enforcement in areas that fall within Congress's Article I, Section 8 powers, without statutory implementation by Congress.").

${ }^{178}$ Compare Henkin, supra note 10, at 1559 ("[It makes no sense] that questions of international law should be treated as questions of state rather than federal law...."), 
authority to exercise its treaty power in areas beyond its enumerated powers (as Missouri $v$. Holland held), or is the treaty power subject to Tenth Amendment limitations reserving certain powers to the states? ${ }^{179}$ Do federal courts have authority to consider claims brought under a treaty where the political branches have failed to provide implementing legislation executing the treaty? ${ }^{180}$ It is precisely on questions of authority-specifically, who has authority to implement, interpret, and enforce international law in the U.S.-that the two approaches both converge (in examining these questions) and diverge (in the answers they give to these questions). While diametrically opposed on where they come out, as two sides framing a prominent debate, traditionalists and revisionists essentially ask the same set of questions regarding authority. For the purposes of this Article, I

Jessup, supra note 15, at 742 ("[Judicial precedent indicates] that international law constitutes a 'federal general common law."), Koh, supra note 10, at 1827 (“[U]nder current practice, federal courts regularly incorporate norms of customary international law into federal law."), Neuman, supra note 10, at 384 ("The [s] tates have no reserved sovereignty to act on the international plane; the Constitution was designed to take that away from them."), and Stephens, supra note 10, at 397 ("[T] he determination of the content of customary international law and of whether or not it applies in a given situation is a federal question, which triggers federal court jurisdiction and on which federal court decisions are binding on the states."), with Bradley \& Goldsmith, Critique of the Modern Position, supra note 11, at 817 ("[Viewing CIL as part of a federal common law] is founded on a variety of questionable assumptions and ... is in tension with fundamental constitutional principles."), and Bradley \& Goldsmith, Current Illegitimacy, supra note 11, at 349 ("[I]f [CIL] is not federal law, federal courts are not to apply it unless they determine that it is part of state law.").

${ }^{179}$ Compare Golove, supra note 8, at 1081-82 (arguing that the Tenth Amendment does not create subject matter limitations on the treaty power because the latter is a power delegated to the federal government), with Curtis A. Bradley, The Treaty Power and American Federalism Part II, 99 MICH. L. REv. 98, 111-18 (2000) (replying to Professor Golove and arguing that federalism concerns limit the treaty power), and Bradley, Treaty Power, supra note 11, at 434-36 (claiming congressional treaty power is subject to Tenth Amendment limitations reserving certain powers to the states).

${ }^{180}$ Compare Damrosch, supra note 56, at 527 (questioning whether non-selfexecuting declarations have either domestic or international effect as regards apparently self-executing treaties), Flaherty, supra note 56, at 2151-52 (focusing on eighteenth-century British and American history to argue that the traditional understanding of treaties as self-executing is correct), and Carlos Manuel Vazquez, Laughing at Treaties, 99 Colum. L. REV. 2154, 2169-73 (1999) (analyzing the text of the Supremacy Clause to argue that treaties of the United States do not require implementing legislation to assume authority as law), with Yoo, Globalism and the Constitution, supra note 56, at 2040-69 (presenting a historical argument that treaties should be considered nonself-executing in order to preserve the important distinction between domestic and international policy-making), and Yoo, Treaties and Public Lawmaking, supra note 56, at 2233 ("[S]elf-execution would have the unfortunate effect of reading out of our Constitution important aspects of the separation of powers and federalism, and would also undermine the principle of popular sovereignty."). 
am particularly intrigued by the ways in which this debate over authority clashes on the issue of federalism, ${ }^{181}$ with the national orientation of the traditional approach on one hand and the state and local orientation of the revisionists on the other.

I agree with the traditional view that the Constitution provides a robust role for the federal government in domestic implementation of human rights law. In this Article, I provide a different type of insight about the federal role. In outlining possible ways in which the federal government can share authority with state and local governments, this Article resists a zero-sum approach to the question of authority and suggests that norms both trickle down to subfederal governments and trickle up to the federal government. ${ }^{182}$ Rather than focus on the extent of the federal government's power to implement, interpret and enforce international law, this Article questions why all three branches of the federal government take a minimalist approach in exercising this power, and suggests processes for encouraging greater intergovernmental cooperation. As regards the executive branch and Senate, this minimalist approach suggests either lack of political will or the presence of other priorities that crowd out attention to treaty ratification and implementation. In the context of the federal judiciary, the reluctance to invoke or rely on international law may reflect efforts by the bench to position the judiciary strategically vis-à-vis other branches. ${ }^{183}$

Whatever the explanation, the state and local activity described in Part II suggests that subnational units of government are filling part of the vacuum created by the federal government's minimalist approach to human rights lawmaking. More than performing a gap-filling function, this state and local activity is directed largely at fostering greater dialogue with and involvement by the federal government in human rights lawmaking. As discussed above, state and local initiatives in the

${ }^{181}$ While I am also intrigued by the ways in which concerns regarding separation of powers among the federal branches factor into this debate, these concerns are largely outside the scope of this Article.

${ }_{182}$ For an indication that the position advanced in this Article is consistent with (though not identical to) the traditional view, see discussion supra note 17 of Koh, supra note 10 .

${ }^{183}$ See Benvenisti, supra note 48 , at 173-75 (suggesting that judicial timidity is not motivated by a lack of courage or knowledge, but rather is result of deeper factors such as political advantage and opportunity to exert control over other branches of government); see also Knop, supra note 21, at 502 (disagreeing with the common view that "judges must still be educated, encouraged, and acculturated to apply international law properly"). 
context of women's human rights and the death penalty signal coordinated efforts toward enlisting the federal government to implement, respectively, CEDAW and a death penalty moratorium.

The process through which individuals and other actors demand that government (at whatever level) convert abstract principles into concrete law is captured by Cass Sunstein's observation that " $[\mathrm{n}]$ orm cascades occur when societies are presented with rapid shifts toward new norms." 184 This occurs "[w] hen the lowered cost of expressing new norms encourages an ever-increasing number of people to reject previously popular norms, to a 'tipping point' where it is adherence to the old norms that produces social disapproval." 18.5 As examples of norm cascades, Professor Sunstein cites "the attack on apartheid in South Africa, the fall of Communism, the election of Ronald Reagan, the rise of the feminist movement, and the current assault on affirmative action.,"186

The concept of norm cascades is a useful one in analyzing the ways in which state and local adoption of human rights norms (either in binding laws or nonbinding resolutions) can lead to national acceptance of these norms, reflected by policy change through federal legislation. Perhaps the most dramatic example of this phenomenon is the role that state and local anti-apartheid laws played in securing enactment of the federal Comprehensive Anti-Apartheid Act in $1986{ }^{187}$ A more recent example is the role that state and local antiBurma laws played in helping to pave the way for federal legislation on Burma. ${ }^{188}$ Ironically, the Supreme Court found that the very federal law that state and local governments encouraged Congress to pass preempted the Massachusetts state law. ${ }^{189}$ However, Crosby leaves open

${ }^{184}$ CASS R. Sunstein, Free MarketS AND SOCIAL JuStice 38 (1997).

${ }^{185} \mathrm{Id}$.

$186 \mathrm{Id}$.

${ }^{187}$ See Comprehensive Anti-Apartheid Act of 1986, Pub. L. No. 99-440, $\$ 606,100$ Stat. 1089, 1115-16 (1986) (providing states and localities with temporary discretion to enact anti-apartheid contract restrictions more secure than those promulgated by the federal government); see also Byron Rushing, Presentation on International Law and the Work of Federal and State Governments Panel, The American Society of International Law (ASIL) Annual Meeting (Apr. 4-7, 2001) (transcript on file with author).

${ }^{188}$ See Omnibus Consolidated Appropriations Act, 1997, Pub. L. No. 104-208, $\$ 570,110$ Stat. 3009, 3009-166-67 (1997) (allowing the President to impose sanctions against Burma by executive order until Burma improves its human rights practices and makes its government more democratic); see also Rushing, supra note 187, at 3-4 (stating that Massachusetts passed the law "in order to put pressure on the federal government").

${ }^{1 \times 9}$ Rushing, supra note 187, at 5 ("[The Crosby opinion] said that we had been 
the possibility of enactment of state and local initiatives that incorporate human rights norms domestically, so long as these initiatives are not preempted by federal law. ${ }^{1.90}$

In international relations theory, political scientists Martha Finnemore and Kathryn Sikkink describe a three-stage process through which a norm's influence in the international community can be understood: (1) the emergence of the norm; (2) the broad acceptance of the norm (or norm cascade) following a "tipping point," at which "a critical mass of relevant [S] tate actors adopt the norm"; and (3) the internalization of the norm. ${ }^{191}$ The internalization of international norms into domestic law involves both vertical and horizontal communication among transnational networks of various government actors (including judges) as well as nongovernmental actors linked through technology, conferences, and other initiatives that facilitate globalization. ${ }^{192}$ Harold Koh explains that this internalization process facilitates States' obedience to international law. ${ }^{193}$ This Article suggests that dialogic federalism may be a vehicle for the cascading and internalization of norms.

The dialogic approach to human rights lawmaking explored in this Article examines how international norms internalized at the subnational level can be transmitted back up to the national level for fuller translation of these norms into federal law. Of course, adoption of these norms at the federal level may then lead to preemption of the very state and local laws that paved the way for federal action-a di-

preempted by the legislation that we of course helped to pass in the United States Congress.").

${ }_{190}$ While Crosby leaves open the possibility of enactment of state and local laws that promote external policy initiatives as well, the Court held that the Massachusetts antiBurma law was "an obstacle to the accomplishment of Congress' full objectives under the Federal Act." Crosby v. Nat'l Foreign Trade Council, 530 U.S. 363, 373 (2000).

$\rightarrow$ Martha Finnemore \& Kathryn Sikkink, International Norm Dynamics and Political Change, 52 INT'L ORG. 887, 895 (1998).

19.2 See KECK \& SikKINK, supra note 96, at 3 (describing how activists, organized around a shared idea or cause, communicate transnationally to "promote norm implementation, by pressuring target actors to adopt new policies, and by monitoring compliance with international standards"); Slaughter, International Law, supra note 95, at 527-28 (discussing interactions among "the three domestic branches of government in each State transnationally with one another").

${ }^{193}$ Koh, supra note 96, at 626 (explaining that nations obey international law "because of a transnational legal process of interaction, interpretation, and internalization”); Harold Hongju Koh, Why Do Nations Obey International Law?, 106 YALE L.J. 2599, 2659 (1997) ("A transnational actor's moral obligation to obey an international norm becomes an internally binding domestic legal obligation when that norm has been interpreted and internalized into its domestic legal system."). 
lemma that may or may not create disincentives for subfederal action. $^{194}$ Both case studies in Part III demonstrate how this two-way transmission is assisted by dynamic interactions between local, national, and transnational advocacy networks that facilitate the translation of international law into language that is more broadly accessible and relevant to the general public. ${ }^{195}$ By focusing on this dynamic process, this Article suggests that even the adoption of nonbinding norms (such as resolutions) at the state and local level can serve as a vehicle for the implementation of human rights. ${ }^{196}$ Dialogic federalism envisions formal structures constrained by constitutional law (i.e., hard law), through which both soft and hard law norm development are likely to occur at the state and local level in ways that are more visible, manageable, and intelligible. Along with other scholarship on international lawmaking within federal systems, ${ }^{197}$ the dialogic approach suggested here may also serve to suggest new ways in which domestic politics can intersect with international negotiations on human rights.

The process of not only transmitting but also translating international law through networks of subnational government and nongovernment actors performs a dual function. First, as Sunstein's theory

${ }^{194}$ See Rushing, supra note 187, at 3-4 (noting this dilemma in the context of the federal law preempting the Massachusetts Burma law); supra note 189 and accompanying text (discussing the preemption of state law by federal law in the Crosby case).

${ }^{195}$ See KECK \& SikKINK, supra note 96, at 1-3 (describing how transnational advocacy networks promote their policy agendas by framing those agendas to make them resonate for local audiences); see also Fung et al., supra note 100, at 2-3 (describing a system by which international firms would compete to be recognized as ethical employers, thereby ratcheting up international labor standards).

${ }^{196 ;}$ See Steve Ratner, Does International Law Matter in Preventing Ethnic Conflict?, 32 N.Y.U. J. INT'L L. \& POL. 591, 698 (2000) (citing the virtues of taking soft law into account in analyzing norm development and suggesting that the "reluctance to incorporate the element of softness into explanations of compliance" may relate to "an implicit assumption that hard law will affect behavior more than will soft law"); see also Chinkin, supra note 118, at 31-34 (discussing compliance with nonbinding norms).

197 See, e.g., Bermann, supra note 101, at 59 (describing how subnational actors have consulted with their national governments regarding their views on proposed trade agreements); Daniel Halberstam, Comparative Federalism and the Issue of Commandeering, in FEDERAL VISION: LEGITIMACY AND LEVELS OF GOVERNANCE IN THE U.S. AND THE E.U. (Kalypso Nicolaidis \& Robert Howse eds., forthcoming 2001) (manuscript at 1) (comparing Germany's and the United States' doctrines on commandeering), available at http://papers.ssrn.com/paper.taf?abstract_id=254147).

${ }^{198} \rightarrow$ Robert D. Putnam, Diplomacy and Domestic Politics: The Logic of Two-Level Games, 42 INT'L. ORG. 427, 434 (1988) (describing how international negotiators must play a two-level game by attempting to satisfy players at the national and international levels). 
of norms cascades suggests, the process of translating human rights norms (even in nonbinding resolutions) by ever-increasing numbers of nonfederal government units pushes adoption of the norm to a "tipping point." At the tipping point, a relevant mass of actors rejects a previously popular norm or status quo and adheres to the new norm. ${ }^{199}$ A second and equally important function that this normtranslation process performs is in increasing what Professor Daniel Halberstam calls the viscosity of international law. ${ }^{200}$ While Professor Louis Henkin is surely correct in famously observing that "[i]t is probably the case that almost all nations observe almost all principles of international law and almost all of their obligations almost all of the time," ${ }^{201}$ nevertheless, " $[\mathrm{t}]$ here are many instances where a $[\mathrm{S}]$ tate is admittedly in violation" of international law. ${ }^{202}$ As Halberstam points out, "even deliberate and considered violations of international law continue to be a practical possibility. ${ }^{203}$ Because international law is a low-viscosity system, noncompliance occurs "without irreparably tearing the fabric of the governing legal orders," in contrast to a high-viscosity system (such as the U.S. constitutional law system) in which "the compliance pull preventing exit is quite high, and the costs of noncompliance are both certain and great. ${ }^{204}$ Incorporating human rights norms into lo-

199 See SunSTEIN, supra note 184, at 38 ("[T] he lowered cost of expressing new norms encourages an ever-increasing number of people to reject previously popular norms, to a 'tipping point' where it is adherence to the old norms that produces social disapproval."); see ، $\rightarrow$ Finnemore \& Sikkink, supra note 191, at 895 (describing how, at the "tipping point," a "critical mass of relevant state actors adopt the norm").

${ }^{201}$ Halberstam, supra note 197 (manuscript at 10). Halberstam has also commented:

Just as the 'viscosity' of a liquid reflects the forces of adhesion and friction that act on a body moving through the fluid substance, so too, the viscosity of a legal system may be viewed as a combination of the adhesive force of its norms, i.e. the compliance pull that its norms exert on legal actors, and the friction caused by non-compliant action, i.e. the real costs that actors incur by noncompliance.

Id. (manuscript at 10) (relying on Thomas M. Franck, The Power of Legitimacy AMONG NATIONS 26 (1990), in which Franck developed the concept of "compliance pull”; and Harold Hongju Koh, How Is International Human Rights Law Enforced?, 74 IND. L.J. 1397, 1400 (1997), in which Koh discusses the elements of compliance, namely, the awareness and acceptance of a rule for external, instrumental reasons).

${ }^{201}$ LOUIS Henkin, HOW NATIONS BeHAVE 47 (2d ed. 1979); see also Koh, supra note 193, at 2599 (noting that empirical surveys have borne out this statement).

${ }^{202}$ HENKIN, supra note 201, at 43; see also id. at $68-87$ (discussing reasons for the persistence of violations).

${ }^{2013}$ Halberstam, supra note 197 (manuscript at 12).

${ }^{204}$ Id. (manuscript at 11) (relying on AlberT O. Hirschman, EXIT, VOICE AND LOYALTY: RESPONSES tO DECLINE IN FIRMS, ORGANIZATIONS, AND STATES (1970)); see also GeORGE W. DOWNS \& DAVID M. ROCKE, OptIMAL IMPERFECTION? DOMFSTIC 
cal law, state and local initiatives-particularly those that are legally binding-may increase the viscosity of human rights law in the United States.

In performing these two important functions, state and local initiatives incorporating human rights standards may facilitate legally enforceable commitments at the national level. Far from adopting the revisionist perspective that states should displace the federal government in implementing, interpreting and enforcing international law, however, this Article argues that the federal government should play a strong leadership role in coordinating information regarding state and local efforts to publicize best practices, to distill lessons learned, and to extract workable norms for possible adoption at the national level. Moreover, this Article stops short of endorsing more ambitious proposals to involve state and local governments directly in the treatymaking process. ${ }^{20 ;}$ While recognizing that subnational government units have participated on a limited basis in the World Trade Organization (WTO), ${ }^{207}$ in trade negotiations, ${ }^{208}$ and in various international

UNCERTAINTY AND INSTITUTIONS IN INTERNATIONAL RELATIONS 77 (1995) (noting that GATT "establish[es] sanctions for noncompliance that are low enough to allow politicians to break the agreement when interest group benefits are great, but high enough to encourage states to obey the agreement most of the time and thereby prevent trade wars"); Benvenisti, supra note 92, at 196 (discussing "the opportunities for governments and small groups to evade specific [treaty] clauses with impunity").

20:3 Note that the bindingness of state and local initiatives incorporating human rights norms matters more in performing the viscosity-strengthening function than it does in performing the tipping-point function. Here, we may consider Halberstam's helpful observation that

[t] he viscosity of a legal system is thus related to, but different from, the characteristics of "hardness" or "softness" of legal rules, which refer principally to the degree to which legal rules are binding as a normative matter as opposed to the degree to which they are observed as a practical matter.

Halberstam, supra note 197 (manuscript at $11 \mathrm{n} .42$ ) (cit $\rightarrow$ C.M. Chinkin, The Challenge of Soft Law: Development and Change in International Law, 38 INT'L \& COMP. L.Q. 850, 851 (1989), which describes hard laws as those that "specify the exact obligations undertaken or the rights granted" and soft laws as those that provide only for "the gradual acquiring of standards or for general goals").

See, e.g., Spiro, supra note 17, at 569 ("I also propose that subnational entities be afforded some mechanism to discretely [sic] associate with formal human rights regimes.").

${ }_{207}$ Id. at 592-93. Spiro describes the plurilateral Agreement on Government Procurement's opt-in model, in which a "sub-central" government has the option of accepting the treaty regime by notifying the WTO through the relevant central government. Id. at 592. Central governments remain the only formal parties to the agreement, and are responsible for the violations by subnational governments but only with regard to those "whose acceptance has been notified." Id. As of November 1997, Spiro notes that " $\mathrm{t}]$ hirty-seven states ha[d] indicated their assent to the treaty terms to the office of the U.S. Trade Representative, which in turn ha[d] transmitted accep- 
environmental conferences, ${ }^{209}$ examination of state and local government involvement in such external international arenas is beyond the scope of this Article. ${ }^{210}$ As for internal domestic incorporation of human rights law, however, a stronger coordination role by the national government is needed because "the Constitution created the institutions of the federal government precisely to avoid such balkanization of foreign policy and international affairs." ${ }^{211}$ An Inter-Agency Working Group (along the lines of theme established under Executive Order 13,107 ) could play such a coordination role.

Ultimately, it is in the federal government's national interest to become more involved in monitoring and nurturing these local efforts. Under international law, the federal government is responsible for treaty violations of subnational governments and their officials. ${ }^{212}$ Even assuming international law eventually establishes liability for subnational governments, ${ }^{213}$ national governments will likely continue

tance to the WTO secretariat." Id. at 592-93. Significantly, Spiro points out that the "Massachusetts state law restricting procurement from corporations doing business in Burma ... [became] the subject of a WTO complaint [asserted] by the European Union and Japan ... [and that it did] not appear to have resulted in the equivalent of deaccession by subfederal governments." Id. at 593 .

${ }^{2118}$ See Bermann, supra note 101, at 59 (discussing states' roles in consulting with the United States regarding trade agreements).

${ }^{209}$ See Spiro, supra note 17, at 594-95 (discussing involvement of subnational governments at the 1992 Rio Conference on the Environment as well as at the more recent Habitat II Summit in Istanbul).

${ }^{210}$ For comparative investigations of the practice of other European countries and notably Germany, whose subnational governments participate in the European Union, see Naomi Roht-Arriaza, The Committee on the Regions and the Role of Regional Governments in the European Union, 20 HASTINGS INT'L \& COMP. L. REV. 413, 423-30 (1997), comparing Germany's, Belgium's, and Austria's national arrangements that permit subnational input into decisions on European-level issues; Halberstam, supra note 197 (manuscript at 19-31), comparing Germany, the United States, and the European Union; Tushnet, supra note 38, at 1065-71, describing constitutional federalism in the United States; and Juliane Kokott, Federal States in Federal Europe: The German Länder and Problems of European Integration, in NATIONAL CONSTITUTIONS IN THE ERA OF INTEGRATION 175, 176 (Antero Jyränki ed., 1999), discussing "the interaction between EU-level federalism and German federalism."

${ }^{211}$ Koh, supra note 10, at 1841.

${ }^{212}$ Bermann, supra note 101, at 60.

${ }^{213}$ Going a step further than I am prepared to go in this Article, Professor Spiro has called for the establishment of "condominium" responsibility, "under which both a central government and its political subdivisions would be held legally accountable," an approach that would be "similar to joint and several liability under tort law." Spiro, supra note 17, at 588-89. Establishment of such liability may be consistent with other recent developments in international law establishing criminal responsibility for individuals accused of war crimes. See, e.g., Rome Statute of the International Criminal Court Statute, June 17, 1998, 37 I.L.M. 999, 1002. Joint and several liability for subna- 
to be on the hook so long as these governments continue to assert control over their constituent units.

At the same time, by cultivating the ability of state and local initiatives to serve as a vector for incorporation of human rights law, the U.S. government could develop a broader and deeper commitment to human rights. By theorizing new modes of democratic deliberation, dialogic federalism could enable the federal government to deepen its partnerships with subnational governments, through engagement in dialogue and collaboration, which these state and local initiatives invite.

tional and national governments might also be consistent with recent cases concerning civil liability for corporations responsible for human rights violations. See, e.g., Wiwa v. Royal Dutch Petroleum Co., 226 F.3d 88, 108 (2d Cir. 2000) (reversing dismissal of suit for forum non conveniens), cert. denied, 121 S.Ct. 1402 (2001); Aguinda v. Texaco, Inc., 142 F. Supp. 2d 534, 544 (S.D.N.Y. 2001) (granting Texaco's motion to dismiss for forum non conveniens); Doe v. UNOCAL Corp., 110 F. Supp. 2d 1294, 1312 (C.D. Cal 2000) (granting UNOCAL summary judgment on plaintiff's Alien Tort Claims Act and Racketeer Influenced and Corrupt Organization Act claims and dismissing plaintiff's state law claims without prejudice), aff d, 248 F.3d 915, 931 (9th Cir. 2001) (affirming dismissal of defendant French corporation for lack of personal jurisdiction). 